\title{
The Dredgings of the Marine Biological Association (1895-1906), as a Contribution to the Knowledge of the Geology of the English Channel.
}

\author{
By
}

R. Hansford Worth, F.G.S.

With Plates VI-XVII (including five charts) and four figures in the Text.

\section{INTRODUCTION.}

Investigation of the geologic problems connected with the English Channel is no new matter. Setting aside all speculations deriving from the study of its coast-line, the first serious examination of the bed of the Channel was made by R. A. C. Austen, and his results published in the Proceedings of the Geological Society, 13 June, 1849. Although, as he states, he had examined the sea-bed with dredge and sounding-lead he has little to say as to its lithology. But none the less his work is a notable contribution to our knowledge, and his conclusions bear well the test of subsequent discoveries. Following Austen, in 1871, Delesse published his Lithologie des Mers de France, in which considerable attention is given to the Channel; and the lithology of its coastal deposits, and to some extent of the sea-bed, is considered in detail. But, valuable as this work is, its chief interest lies in the information given as to the nature of the sea-bottom, the grade and extent of the varying deposits. Austen and DeLESse alike, and in agreement, point out the large areas of the Channel bed which are occupied by stones, boulders, and pebbles of some size, and argue on much the same lines as to the conditions which have formerly existed there.

In 1879 the petrology of the English Channel was first seriously attacked. Mr. A. R. Hunt then published in the Transactions of the Devonshire Association a paper "On a Block of Granite from the Salcombe Fishing Grounds." This was followed in 1880, 1881, 1883, 1885 , and 1889 by five papers entitled, "Notes on the Submarine Geology of the English Channel off the South Coast of Devon." And, in 1896, the same author added later information in his paper on 
"West Country Geological Problems," published in the same Transactions. It is noteworthy that Mr. HunT was on the track of a shore problem when his attention was thereby directed to the large boulders occasionally trawled by the fishermen off the south coast of Devon, and it is to these boulders that he confines his work. None the less he stands the first to really approach the matter from the point of modern petrology.

Meanwhile, in 1886, the late R. N. Worth had taken up the question on very similar lines, and in the Quarterly Journal of the Geological Society, in August of that year, he reported the existence of a submarine Triassic outlier off the Lizard; in a subsequent paper, in the Transactions of the Royal Cornwall Geological Society, he dealt with a similar discovery off the Dodman.

Here the matter rested until, in 1895, Dr. Allen commenced an investigation into the fauna and bottom-deposits near the thirtyfathom line from the Eddystone grounds to Start Point. In the course of this work numerous samples of the bottom-deposits were taken, and in vol. v, no. 4 , of this journal will be found, incorporated in Dr. Allen's paper, some notes on these. The geologic results were subsequently dealt with at greater length by the present writer in the Transactions of the Devonshire Association, 1899, xxxi. pp. 356-75 ("The Bottom-Deposits of the English Channel from the Eddystone to Start Point, near the Thirty-Fathom Line"). Since 1899 the inshore grounds nearer Plymouth have also been subjected to an examination on similar lines, and additional geological information obtained which has not hitherto been published.

In the present paper it is intended to incorporate the whole of the previous results with the work done in 1906, of which latter an account is given by Mr. Crawshay in the preceding pages. By Mr. A. R. Hunt's kind consent an abstract of his petrographic work is added by way of an appendix, which, with other short appendices, will bring together the whole of our present knowledge of the geology and petrology of the western part of the English Channel.

Mr. Crawshay's long line of dredgings, extending to a point near 50 miles S. $16 \frac{1}{2}^{\circ} \mathrm{W}$. from the Eddystone, and $\mathrm{Mr}$. Hunt's specimens, which reach 43 miles $\mathrm{E}$. of the Eddystone, between them cover a large area; while to the westward for a distance of 36 miles we have the records of the late R. N. Worth. The difficulties which exist where no field work is possible are naturally considerable, but, as the writer has endeavoured to show elsewhere, very definite results, within certain limits, may be obtained by an inquiry of this kind. Other usual observations being barred, lithology becomes of the utmost importance,

NEW SERIES. - VOL. VIII. NO. 2. 
and the microscope invaluable, since much of the minuter evidence afforded by a rock is as direct and positive as that on a large scale. It has been impossible to microscopically examine every variety found, but one hundred sections in all have been prepared, and it is hoped that most of the rocks may safely be grouped around those thus represented.

Before entering upon detail, it may be well to pass in review the manner in which the problem has been attacked by the various investigators. Austen used both sounding-lead and dredge, he differentiated the textures of the deposits, giving such statements as that the gravel was of the size of almonds, beans, olives, walnuts, or the ground was stony, or large angular and rounded blocks occurred; he mentions flint, granite, black granite, tin-stone, serpentine, etc., but with no clearer lithological definition, and he records any shells of littoral species found in the deeps. His observations covered the whole Channel bed, but not closely, and extended from the Nymph Bank to near Dover.

Delesse, with greater attempt at detailed location, but with less information as to the size of the constituents of gravels, maps out the Channel, discriminating between areas covered by 'argile,' 'craie,' 'sable,' 'sable riche en coquilles,' 'sable sur les roches pierreuses,' 'roches pierreuses,' 'roches en pierres désagregées,' and 'roches en pierres pourries ou décomposées.' He trusted to the sounding-lead for his samples, and none is recorded as coarser than gravel, while none which came from a greater depth than 28 metres is lithologically examined in detail; most were obtained very near the French coast.

Hunt chiefly derived his material from the occasional boulders captured in fishermen's trawls off the south coast of Devon; the more part of these were decidedly heavy, ranging from about 3 to about 12 cwt. All were examined microscopically by modern methods.

R. N. WorTH was supplied with blocks and stones of some size which had become entangled in long lines or bolters; he, too, examined the rocks microscopically.

The Association has conducted systematic dredgings and endeavoured to obtain fair samples of the bottom-deposits, including sands, gravels, pebbles, and small boulders. Its gear has not permitted the capture of the larger blocks which undoubtedly occur, but three of these have been traced which have been obtained by fishermen, and hand specimens taken. Where pebbles have been dredged, in the later work at least, these have been entirely depended on for information as to the lithology of the station; in the earlier work, where pebbles were searce, the sand was examined in detail also. The superior facilities 
which the Association enjoys advantages it greatly, but our debt to the earlier workers remains undiminished, and in many instances they have preserved evidence of great importance, which must otherwise have been lost.

PETROLOGY.

To avoid the confusion which might arise from the system of numbering the dredgings, whereby three distinct sets of samples have all been numbered from 1 onward, the following method has been adopted. Actual hand specimens from Dr. Allen's first dredgings are referred to by the reference which the slides bear in the writer's collection, similarly specimens from the second set of dredgings further inshore, this will always be found to be a double number, such as " $356 / 1$ ", with sometimes a letter added also. In those cases where sands only have been examined, all of which occur in Dr. Allen's dredgings alone, the station number already published in the Journal is used, prefixed by the letter "A." The most recent stations, of last year's work, have the letter "M" set before the number; and Mr. Hunt's own figures are used with the letter " $\mathrm{H}$ " prefixed. Mr. R. N. Worth's specimens bear a number prefixed to which is the letter "W."

Where more than one rock is described from a station small letters are added after the number, by which the various specimens are discriminated.

With reference to the dredgings taken last year, the rule has been adopted that if several varieties or specimens of one class rock have to be described, those are set first which are nearest the Eddystone, and of those at equal distance precedence is given to the more western.

Throughout, the abbreviation "Edd." represents the word Eddystone.

\section{GRANITES AND ALLIED ROCKS.}

A large number of specimens, generally distributed over the area examined, fall within the popular acceptation of the term 'Granite,' but the greater part of these when submitted to microscopic examination must be transferred to the Quartz-diorites in consequence of the distinct preponderance of plagioclase felspars. Since it is impossible to be certain in which class to place many of the specimens on mere inspection, and it has been out of the question to section all, those as to which any doubt exists are hereafter collected under the head of ' Granitoid Rocks.'

\section{GRANITES.}

Boulder. S.S.W. Start, 15 miles. Weight about $8 \mathrm{cwt}$.

A fine-grained white granite, with very uniformly disseminated black mica. The little felspars are bright and fresh, and the simple 
twinning of orthoclase shows in almost every one. Some of the felspars are slightly tinted yellow by powdery decomposition products. The mica inclines to a reddish bronze lustre. The general structure of the rock is very uniform.

In the section a portion of the felspars is seen to be slightly clouded. The more part are orthoclase, but the orthoclase at places encloses small crystals of triclinic felspars, of which larger areas also occur. There is a tendency to zonal structure in some of the felspars, and there are a few very small areas of graphic structure. The quartz contains fairly numerous fluid inclusions with bubbles, some apparently empty or gas-filled cavities, and frequent hair-like microlites, probably apatite. Almost all the mica is brown and intensely pleochroic, but associated with this is a little which is colourless and shows no pleochroism. Apatite is present.

Boulder. S.W. by S. $\frac{1}{2}$ S. Bolt Head, 19 miles. Weight 833 lbs.

A coarse rock of granitic texture. The felspar gives bright cleavage surfaces, but is largely yellow-stained by dusty decomposition products; there are no good crystal outlines. Black mica occurs in patches of granular texture.

The large orthoclase areas are seen in section to be intergrown with plagioclase, narrow irregular and only approximately parallel strips of which penetrate the orthoclase; all the strips in each crystal extinguish together and in a different position to the main crystal, and all show lamellar twinning, the direction of which is constant throughout the crystal; thus the intergrowth gives rise to micro-perthite. Those felspars, the less numerous, which are clouded with decomposition products, all appear to be triclinic. The quartz presents numerous fluid inclusions, and in places is crowded with other inclusions which appear as a fine black dust; there are also small acicular microlites. The mica passes from olive-brown to dark green on rotation, but there is a little that is almost colourless.

\section{IM. 58 b. S. $22^{\circ}$ W. Edd., 39 miles.}

Medium textured granitic rock, pale flesh-coloured felspar, dark and light mica. Structure granitic. Felspars clouded brown. There are small patches of very well defined graphic structure, here the felspar is clearer. Multiple twinning can still be detected in places. Nearly half the felspar is still almost clear; none of this shows plagioclase twins. Much colourless widely biaxial mica. Quartz plentiful, crowded and lined by fluid inclusions, all with bubbles ; many of these inclusions are of comparatively large size. There is a little apatite, and in one part of the slide a chloritic mineral fills the cracks in a felspar. 
FIg. 1.

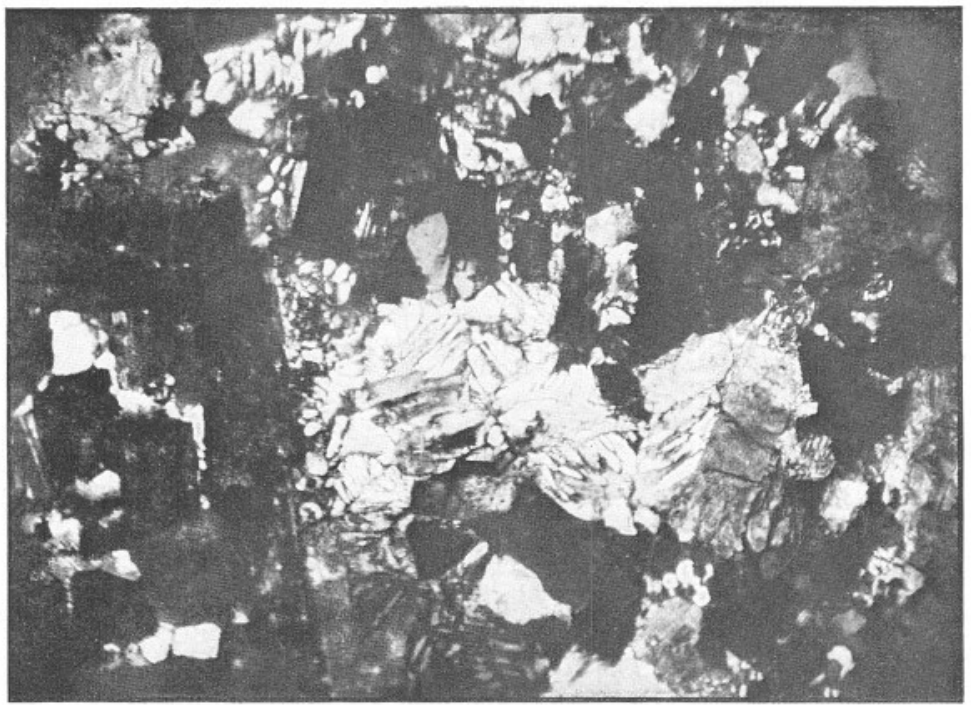

M. 11a. S. [26 W. Edd., $17 \cdot 8$ miles. Micro-pegmatite. Crossed nicols. $\times 29$.

\section{Fig. 2.}

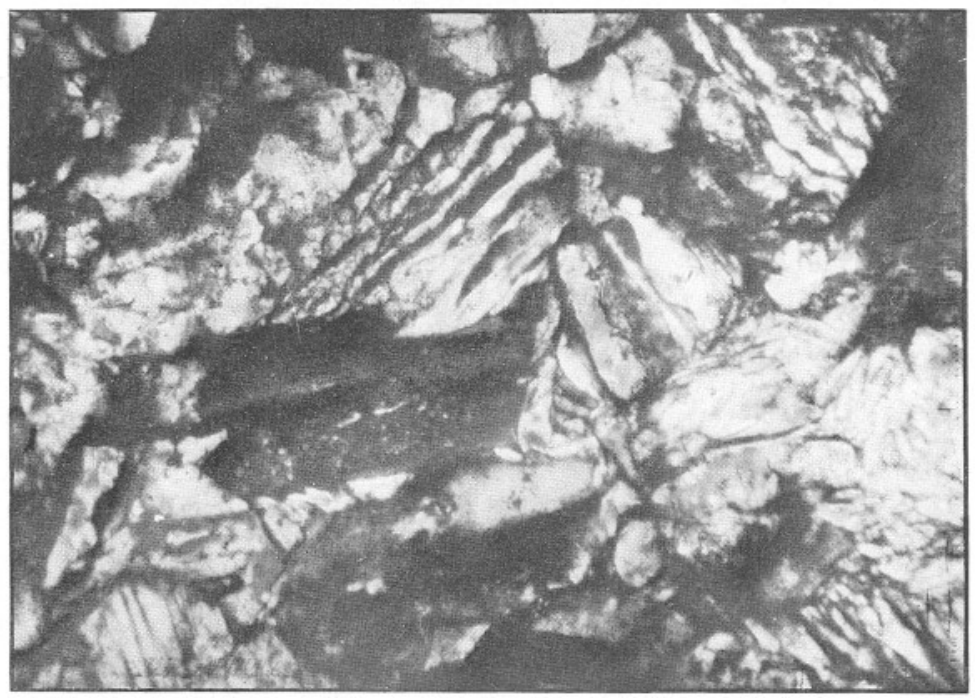

M. 11a. S. $26^{\circ}$ W. Edd., $17 \cdot 8$ miles.

Micro-pegmatite.

Crossed nicols. $\times 97 \frac{1}{2}$. 


\section{MICRO-PEGMATITE.}

\section{11 a. S. $26^{\circ}$ W. Edd., $17 \cdot 8$ miles.}

Red granitoid rock of fine grain, black mica.

Many felspars clouded entirely with red-brown decomposition products. Others, but fewer, almost clear. Some crystals are practically opaque in the centre, clear outside, with successive narrow zones of brown. Graphic structure is well developed; often where it has invaded a felspar crystal there will be included in it small perfect crystals free from this structure. Repeated twinning is rather rare. The fluid inclusions in the quartz are very small, most have bubbles, and extremely rarely a cubic crystal occurs. There is a little dark green biotite and some ilmenite. The graphic structure is the great feature of the slide. (Plate VI, figs. 1 and 2.)

\section{APLITE.}

M. $11 \mathrm{c} . \quad$ S. $26^{\circ}$ W. Edd., $17 \cdot 8$ miles.

A fine grained red granular rock with nests of schorl visible in the hand specimen.

An aplite consisting of quartz and felspar only, except for the tourmaline above mentioned. Structure microgranitic. Felspar red, and somewhat clouded in parts, mainly orthoclase, but plagioclase present. The quartz contains numerous and rather large fluid inclusions, nearly all with bubbles, many with crystal inclusions. Most of the tourmaline is indigo in colour, but some small crystals give brown to blue pleochroism.

This might be a type rock from Dartmoor. It can be matched in situ in the valley of the Tavy toward and below the lower end of Tavy Cleave, and a precisely similar rock was found as a small boulder resting on the rock bed some hundred feet below the surface of the mud at Keyham Extension Works.

M. $27 x$. S. $19^{\circ}$ W. Edd., $18 \cdot 3$ miles.

A schorlaceous aplite very similar to $\mathbf{M}$. 11c., but which has not been microscopically examined.

\section{M. $24 \mathrm{~g} . \quad$ S. $24^{\circ}$ W. Edd., $22 \cdot 5$ miles.}

Granular felsite of rich red colour.

The section exhibits microgranitic structure. All the felspars are more or less clouded, a few considerably, and in some cases the ordinary optical properties are destroyed. Orthoclase distinctly predominates, but plagioclase twinning is not rare. The felspars show rounded outlines, marked in some instances by a narrow line of iron oxide, and flakes of hematite occur in some of the crystals. The quartz shows 
fairly numerous fluid inclusions of very small size. No other mineral is present. The rock must be classed as an aplite.

Similar rocks to $24 \mathrm{~g}$ are $34 \mathrm{e}, \mathrm{S} .28^{\circ} \mathrm{W}$. Edd., $18 \cdot 5$ miles and $14 \mathrm{e}, \mathrm{S} .24^{\circ} \mathrm{W}$. Edd., 20 miles.

\section{FELSITES.}

Under this heading are placed a number of rocks which fall readily into three groups, the first of which consists of two specimens, almost identical in character, and very familiar in appearance to any one who has an acquaintance with the Permian and Triassic rocks of Devon.

M. 27 c. S. $19^{\circ}$ W. Edd., $18 \cdot 3$ miles.

Compact red-purple felsite, with light porphyritic felspars and black mica. Fracture trachytic. Has all the appearance of one of the new red felsites.

\section{41 a. S. $36 \frac{1}{2}^{\circ}$ W. Edd., $26 \cdot 6$ miles.}

Felsite, texture trachytic, colour red-brown, small dull white porphyritic felspars, and a little black mica. Cryptocrystalline groundmass. A few idiomorphic felspars. A few porphyritic quartz crystals with corroded outlines. Well developed, highly pleochroic brown mica. The ground-mass contains numerous microlites, also many small felspars outlined in or largely replaced by hematite. Flakes of hematite are very numerous. A typical red-rock felsite.

The specimens placed in the second group form a series, commencing at the Hand Deeps and terminating M. $62,46.4$ miles S. $25^{\circ}$ W. from the Eddystone. Of these the northernmost example has been subject to considerable mineral alteration; the southernmost is the most fresh, and in the latter the porphyritic constituents are more prominent than in any other. The northernmost is probably alone in that it contains mica. All are strongly reminiscent of rocks elsewhere associated with the Permian and Trias.

\section{4/3d. Slopes of Hand Deeps.}

A grey rock, with a slight shade of green and small purple spots. Small felspars appear, colour buff, all somewhat decomposed. At places the tint of this rock varies to yellow and to purple. There are minute black specks of a hard mineral, and calcite is developed on joint faces.

Microscopically the ground-mass is seen to be crypto-crystalline with much minute calcite, areas of which mineral also occur. Small felspars are scattered through this mass, and are about uniformly divided between orthoclase and plagioclase. Quartz occurs in small patches of interlocked granules. Mica is now almost entirely replaced by pseudomorphs in limonite and magnetite. 


\section{36 e. S. $37^{\circ}$ W. Edd., $17 \cdot 5$ miles.}

Sub-conchoidal fracture. A dull purple rock, with parts more drab in colour, flesh-tinted felspars in a horny matrix.

\section{M. $35 d$. S. $32^{\circ}$ W. Edd., 18 miles.}

Grey, with warm tinge, purple mottling, sub-conchoidal fracture, minute flesh-tinted felspars, mostly much decomposed.

M. 20 a. S. $25^{\circ}$ W. Edd., 20.5 miles.

Compact rock, very like $354 / 3 \mathrm{~d}$. in general appearance, but without the small black grains and the calcite. Rather harder than that rock. Grey in colour with warm tinge. Small flesh-coloured felspars, many of which are decomposed.

M. 21 b. S. $25^{\circ}$ W. Edd., $21 \cdot 2$ miles.

Compact light grey-drab felsite, red mottling, porphyritic quartz.

Crypto-crystalline felsitic ground-mass, in which porphyritic quartz is freely developed; the crystals, although rounded at the angles and at places invaded by the felsitic matter, are largely bounded by straight lines. Minute fluid inclusions are not uncommon, but comparatively the quartz is clear. The felspars are almost formless and ill differentiated from the ground-mass; micro-perthite is indicated in some individuals. There is a small yellow patch of some granular mineral showing brilliant colours between crossed nicols. This same mineral is also sometimes associated with the dusty, somewhat dendritic red oxide of iron which gives the rock its mottling.

M. 62 c. S. $25^{\circ}$ W. Edd., $46{ }^{\circ} 4$ miles.

A green-grey compact rock, with much quartz and fels ar irregularly distributed. The felspar is pink. The porphyritic constituents more prominent than in any of the preceding. Calcite is freely developed on joint faces.

The third group would appear to bear a close relation to the granites which form a prominent feature of the lithology of parts of this area. In this respect they probably stand much as the very hard India-red felsite so freely found on the Hallsands Beach does to the granites of Dartmoor. All are horny in texture and have a subconchoidal fracture.

M. 12 f. S. $26^{\circ}$ W. Edd., $17 \cdot 8$ miles.

No detailed notes taken of this rock.

M. 72 d. S. $23^{\circ}$ W. Edd., 19 miles.

India-red, compact felsite, occasional small red felspars.

M. 9a. S. $31^{\circ}$ W. Edd., $21 \cdot 7$ miles.

Red felsite. Green porphyritic felspars, compact texture.

Ground-mass crypto-crystalline. Felspars much decomposed, the green 
shade being due to a secondary mineral. This traverses the crystals along irregular cracks, and sometimes extends from them a short way into the ground-mass, continuing the line of the crack; it is also generally distributed in the crystal. The less altered felspar is pale red in colour. The green mineral is often fibrous and sometimes granular, it has a high double refraction; apparently we are dealing with epidote. Quartz crystals, somewhat corroded, are rather common, and show a fair number of very minute fluid inclusions with bubbles.

Titanic iron ore is scattered in small grains throughout the slide, but much more freely developed and in larger forms at some places where associated with the green decomposition product above referred to. All the ilmenite is much altered and the smaller crystals are now entirely leucoxene. Apatite occurs, and two much altered areas were once apparently mica.

\section{QUARTZ-DIORITES, DIORITES, DOLERITES, AND DIABASE.}

It is possible that exception may be taken to the manner in which some specimens have been placed in the subdivisions of this group. But the erection and maintenance of hard and fast boundaries, where none such exist in nature, invariably brings the element of personal judgment into play, and in most cases it will be found that ample detail is given to enable the reader to reclassify the specimens to his individual preferences.

No pretence can be made that any more than a few, and those the most representative, of the rocks in this group are here given.

\section{QUARTZ-DIORITE.}

M. $11,1$. S. $26^{\circ}$ W. Edd., $17 \cdot 8$ miles.

Brownish granitoid rock of medium grain. Texture granitic. Felspars clouded light brown, but wherever the structure is not masked by this show very closely repeated twinning. Outside the better defined crystals there is some clearer and probably secondary felspar. Quartz plentiful, traversed by streams of fluid inclusions in two or more directions. The cracks in quartz and felspars alike are ironstained. Hornblende in short, well-marked, prism forms, pleochroism light brown to rich green, two twinned crystals. Ilmenite occurs both in hornblende and in felspars. A few minute crystals of apatite. Quartz hornblende diorite.

M. 72 e. S. $23^{\circ}$ W. Edd., 19 miles.

Pale green rock, with close texture and fine grain, black or very dark green spots of small size.

Micro-granitic structure. The minerals are felspar, quartz, hornblende, magnetite, mica, and augite. The felspars are clear in patches, 
but otherwise much clouded, and all are plagioclases. The quartz contains small and moderately numerous fluid inclusions. Hornblende occurs in two forms; some of it is almost certainly an original mineral, and shows good basal sections, with inclusions, however, of other minerals. Elsewhere the hornblende is more fibrous. The mica has suffered considerable change, if I am right in so identifying a very doubtful mineral, and very little unaltered augite remains. Might almost equally well be classed as a quartz aphanite.

\section{9 e. S. $31^{\circ}$ W. Edd., $21 \cdot 7$ miles.}

Dark grey crystalline rock of rather fine texture. Small felspars of irregular shape and slightly greenish tint, small quartz granules, very clear and bright.

The felspars are plagioclase, much clouded in the centre, quite clear around the margins when crystal outline is shown. Some have obviously been broken. In the felspars occur very numerous small prisms and acicular forms of a clear mineral which may be zoisite. Some felspars show an irregular zone of decomposition products a little within the margin. Most of the quartz areas break down in some part to a mosaic of interlocked granules. The quartz contains fluid inclusions. Strain shadows show in both quartz and felspar. Hornblende, chiefly of an olive shade, is freely developed, much is markedly uralitic. A little chlorite occurs. There is some apatite, and a little ilmenite.

M. 9r. (Same location as last.)

Fine-grained grey rock, felspar and hornblende visible.

Plagioclase felspar, somewhat clouded, occasionally achieving good crystal boundaries, and with a marked tendency to zoning from secondary growth, clearer from decomposition than the centres. Repeated twins somewhat frequent. Minute epidote has been freely developed in many of the felspars, and granules of a mineral which is apparently epidote. Fibrous hornblende is a prominent constituent, occurring in large patches, spreading and extending between the felspar areas; principally it is of a green colour with a tendency to blue; here and there brown and olive shades occur, especially in the interior of some of the larger patches. Quartz is fairly plentiful, with numerous small fluid inclusions, most with bubbles, and a few apparently include very small cubic crystals. Some apatite.

\section{19a. S. $28^{\circ}$ W. Edd., $23 \cdot 3$ miles.}

Dark greenish grey, granular crystalline. Felspars small and slightly green in tint. Fine grain. Texture micro-granitic. The felspars a good deal clouded with pale brown decomposition products, but with frequent clear patches. Some crystals with characteristic 
microcline twinning. By far the greater part is probably, however, oligoclase. Quartz abundant, in large areas of compound structure. The quartz is traversed by narrow streams of fluid inclusions, and contains small rod-shaped crystals, apparently of apatite. Both massive and actinolitic hornblende occur. The pleochroism of the former is pale yellow-brown, dark olive-green. At places a vivid chlorite replaces some of the hornblende. The quartz is slightly ironstained in some of the cracks. Quartz hornblende diorite.

Four rocks apparently similar to the group M. 9e., M. 9r., and M. 19a., are-

(1) M. 11b. S. $26^{\circ}$ W. Edd., $17 \cdot 8$ miles.

Dark grey granitoid rock of fine grain.

(2) M. 11k.

A finer texture of M. 11b.

(3) M. 9q.

Dark grey, fine grained, felspars greenish.

(4) M. 50a. S. $16^{\circ}$ W. Edd., $30 \cdot 9$ miles.

Grey crystalline rock, minutely granular fracture, rather small white felspars somewhat widely scattered.

\section{18 a. S. $29^{\circ}$ W. Edd., $23 \cdot 4$ miles.}

Structure granitic, medium texture, colour grey.

Somewhat clouded felspar, apparently plagioclase. Graphic structure in many crystals. Quartz traversed by broad streams of fluid inclusions, some with bubbles; hair-like microlites also occur, and some larger, recognizable, apatite. There are two micas, the one colourless, the other brown and intensely pleochroic, the extreme tint being a very dark bronze green. Quartz mica diorite.

\section{58a. S. $22^{\circ}$ W. Edd., 39 miles.}

Black and grey granitoid rock, medium grain.

Granitic texture. Felspars in the main clear, but here and there clouded with decomposition products. All apparently plagioclase and probably oligoclase. The quartz clear, with small fluid inclusions and, at places, hair-like microliths. Brown and olive-brown mica, strongly pleochroic. Green and olive hornblende, always associated with mica, but on the whole in less quantity. The hornblende and mica interpenetrate. A fair amount of apatite is present.

The rock must be classed as a quartz-diorite, with hornblende as well as mica present.

M. 80 d. S. $16 \frac{1}{2}^{\circ}$ W. Edd., $48 \cdot 9$ miles.

Fine-grained brown granitoid rock, with black mica, texture granitic. Felspar much altered and crowded with brown decomposition pro- 
ducts. A few crystals appear zoned, some still show repeated twinning. Much quartz, in which fluid inclusions are common; a majority of these inclusions have bubbles. Brown mica. Apatite. Some ironstaining. Quartz mica diorite.

\section{DIORITE}

\section{12 d. S. $26^{\circ}$ W. Edd., $17 \cdot 8$ miles.}

A striking looking rock by reason of the lustre of its constituent minerals. Very dark in colour, consisting as it does of a black mineral in prismatic form, and a clear felspar. Some of the little prisms of the black mineral are as much as $3 \mathrm{~mm}$. in length.

The rock consists of a clear labradorite, in which, however, calcite granules are developed here and there along cracks; and a green monoclinic pyroxene, ægirine, in which a very marked schiller structure has been set up, the microlites being of a dark brown. Minute crystals of pyroxene appear in the felspars. Irregular patches of an iron oxide, apparently magnetite, are common.

\section{35 b. S. $32^{\circ}$ W. Edd., 18 miles.}

A fine grained, dark grey, granular rock with much mica. Besides the dark mica there is obviously a lighter mineral, and the two are very uniformly admixed.

The section shows this rock to be a mica-diorite. Rich brown mica occurs freely in irregular plates, and felspar in mosaic. A minority of the felspar granules are striated, a very few show decomposition products. An occasional crystal of apatite is present and a fair amount of titanic iron ore in small grains. The general appearance of the rock is very fresh.

A similar rock to $\mathbf{M} 35 \mathrm{~b}$. is

\section{M. $79 a$. S. $16^{\circ}$ W. Edd., $48 \cdot 7$ miles.}

Dark grey, close textured, much mica in small form.

M. 9 s. $\quad$ S. $31^{\circ}$ W. Edd., $21 \cdot 7$ miles.

A dark coloured rock, the exterior of which shows large lustrous black hornblende and dark drab and brown felspar. Fracture very uneven and texture coarse.

The felspars in this rock are now almost indistinguishable as such, an occasional very small patch showing repeated twinning being all that remains unaltered; for the rest they have given place to a granular and fibrous mineral of high refraction and double refraction, and apparently colourless, although the larger grains may have a palest shade of green. The rest of the slide is occupied by fibrous pale green hornblende. Ilmenite is common. The structure ophitic. 


\section{DOLERITE.}

M. 14 e. S. $27^{\circ}$ W. Edd., $20 \cdot 3$ miles.

A fine-grained even-textured rock of a distinct green colour. Some iron pyrites show in the hand specimen. Numerous lath-shaped felspar microlites with irregular terminations, all quite fresh and clear. Pale bluish-green fibrous hornblende is quite the most prominent constituent of the rock; there is no general direction pursued by its fibres. Scattered closely throughout the section are very irregular grains of a minutely granular pale brown mineral of strong double refraction when examined with high powers and strong light. Dirty white by reflected light, this is probably leucoxene.

Curious little streams of (?) magnetite occur rather frequently, in forms suggesting that they are reminiscent of some original prismatic mineral.

M. 16 b. S. $29^{\circ}$ W. Edd., 20.9 miles.

Pale green minutely granular rock.

A slide of confused texture. Fibrous green hornblende. Felspar with a tendency to lath-shaped sections. Apparently no quartz. Grain very fine.

M. 21e. S. 25 . W. Edd., $21 \cdot 7$ miles.

A close-textured grey rock, looks much like a grit.

The most prominent feature in the section is the abundance of pale yellowish-green acicular or fibrous mineral in diverging bundles, which often have the appearance of having been drawn together at the middle. Here and there almost colourless, at other places this mineral takes a blue-green tint, and it is almost certainly actinolite. These bundles are largely set in a crypto-crystalline ground-mass, which is freely invaded by shorter prisms of actinolite. There are also felspar crystals of irregular outline, some certainly plagioclase, some possibly orthoclase, and micro-porphyritic quartz is about as frequent as the felspar. There is a considerable sprinkling of grains of titanic iron ore.

M. 80 c. S. $16 \frac{1}{2}^{\circ}$ W. Edd., $48 \cdot 9$ miles.

Clouded white felspars, lath-shaped in part, in part conforming to the interspaces between the augites which constitute the more part of the rock. Portions of the felspars are still quite clear. The augite is in the main quite fresh, but traces of chloritic products occur. Characteristic patches of ilmenite.

\section{DIABASE.}

M. 27 a. S. $19^{\circ}$ W. Edd., $18 \cdot 3$ miles.

Compact dark grey rock, green felspar and hornblende. Augite, hornblende, chlorite, plagioclase, leucoxene, quartz. The augite, pale 
brown, apparently existed in ophitic form; it is now almost entirely replaced by hornblende. The hornblende is chiefly pale green, with a slight blue shade and orange-brown tints along cracks and cleavages. The titanic iron ore is entirely associated with the hornblende, and is present in large forms and branching growths. Chlorite occurs in fairly large areas, and exhibits marked pleochroism from pale brown pink to pale bluish green. The felspars are pale pink, rather fresh in appearance, but sometimes traversed along cleavages by chlorite; they have a tendency to elongated parallelogram section. Quartz shows good crystal outline.

\section{14 v. S. $24^{\circ}$ W. Edd., 20 miles.}

A small hard pebble, distinctly green in colour, and having small somewhat vesicular looking cavities on the surface.

In section, seen to be a network of small lath-shaped felspars set in a grey and green ground-mass. Chlorite is disseminated throughout the slide, and the larger patches, which are not infrequent, are evidently after augite, as they are associated with unaltered remnants of the latter mineral. Calcite occurs, not only mingled with the ground-mass, but also in larger patches; the solution of these has probably left the cavities on the surface of the pebble. There are two or three recognizable crystals of ilmenite and scattered black grains that are either this mineral or magnetite.

\section{15 c. S. $27^{\circ}$ W. Edd., $20 \cdot 3$ miles.}

Greenish hornblendic rock.

Large patches of very pale hornblende. Between these a fibrogranular ground-mass of low double refraction, prismatic and basal sections of zoisite of sufficient size for discrimination occur rather freely. Some iron ore. What other minerals may be present in minute forms cannot be determined.

Zoisite-amphibolite.

\section{22 c. $\quad$ S. $25^{\circ}$ W. Edd., $21 \cdot 9$ miles.}

Dark green rock, massive hornblende.

Shows a very little felspar, and a few patches of augite. In the rest it consists of reedy hornblende of very varying tint, from almost colourless to olive-brown and blue-green, all in light shades.

\section{GRANITOID ROCKS}

M. $31 . \quad$ S. $25^{\circ}$ W. Edd., 15 miles.

Granitic texture. Brown and black, ditto brown.

Felsitic. Brown, fine-grained, granular. 
M. $36 . \quad$ S. $37^{\circ}$ W. Edd., $17 \cdot 5$ miles.

Granitic texture. f. Medium grain, white felspar, black mica.

g. Fine grain, pink, black specks.

Felsitic texture. b. Brown, granular.

M. 33 . S. $25^{\circ}$ W. Edd., $17 \cdot 5$ miles.

Diorite.

M. 11 , M. 12 , M. $13 . \quad$ S. $26^{\circ}$ W. Edd., $17 \cdot 8$ miles.

M. 11. Granitic texture. g. Fine-grained brown, black mica.

M. 12. Hornblende Diorite.

Granitic texture. Red with abundance of mica. Brown of fine grain. Brown of medium grain. Grey.

M. 35 . S. $32^{\circ}$ W. Edd., 18 miles.

Granitic texture. f. Brown.

M. 27. S. $19^{\circ}$ W. Edd., $18 \cdot 3$ miles.

Granitic texture. Pale grey.

M. 26. S. $20^{\circ}$ W., $18 \cdot 4$ miles.

Two quartz-hornblende-diorite pebbles.

M. 34 . S. $28^{\circ}$ W. Edd., $18 \cdot 5$ miles.

Felsitic texture. g. Brown, fine granular.

M. $72 . \quad$ S. $23^{\circ}$ W. Edd., $19 \cdot 0$ miles.

Granitic texture. Medium grain, grey and brown, brown mica. Brown. Red with black mica.

Felsitic texture. c. Porcellanous cream-coloured.

M. 14 . S. $24^{\circ}$ W. Edd., 20 miles.

Granitic texture. k. Red medium grain, and several other varieties. Felsitic texture. t. Close-grained buff.

M. 15 . S. $27^{\circ}$ W. Edd., $20 \cdot 3$ miles.

Granitic texture. Coarse-grained, white felspar, yellow-stained, black mica, much like boulder from S.W. by S. $\frac{1}{2}$ S. Bolt Head, 19 miles.

Fine-grained grey, brown and silvery mica.

Brown with white mica.

M. 20 . S. $25^{\circ}$ W. Edd., 20.5 miles.

Granitic texture. f. Black and white, rather coarse, some hornblende.

e. Black and buff, fine grained, (?) some hornblende.

M. 16 . S. $29^{\circ}$ W. Edd., $20 \cdot 9$ miles.

Granitic texture. Distinctly granitic in appearance, flesh-coloured felspars, orthoclase twins, quartz.

Grey and brown, fine grained.

M. 21 . S. $25^{\circ}$ W. Edd., $21 \cdot 2$ miles.

A few grey granitic rocks. 
M. 30 . S. $21^{\circ}$ W. Edd., $21 \cdot 5$ miles.

Granitic texture. d. Coarse, pale cream-coloured, dark mica.

M. 9. S. $31^{\circ}$ W. Edd., $21 \cdot 7$ miles.

Granitic texture. 1. Medium grain, red felspars.

m. Medium grain, buff felspars.

r. Fine-grained grey.

Medium grain, brown and black.

M. 40 . S. $38^{\circ}$ W. Edd., $21 \cdot 7$ miles.

Granitic texture. Brown, medium grain.

Felsitic texture. Brown, granular.

Greenish grey.

M. 22 . S. $25^{\circ}$ W. Edd., $21 \cdot 9$ miles.

Granitic texture. b. Buff and brown felspar, black hornblende, medium texture.

M. 24 . S. $24^{\circ}$ W. Edd., $22 \cdot 5$ miles.

Felsitic texture. c. Pale grey, compact, white mica. Red.

M. 25 . S. $24^{\circ}$ W. Edd., 23 miles.

Granitic texture. b. Brownish, fine grained, (?) hornblende.

M. 19 . S. $28^{\circ}$ W. Edd., $23 \cdot 3$ miles.

Granitic texture. b. Dark grey, fine grained, much dark mica.

M. 18 . S. $29^{\circ}$ W. Edd., $23 \cdot 4$ miles.

Granitic texture. Brown and grey, medium grain, pale grey felspars.

M. 43 . S. $21^{\circ}$ W. Edd., $28 \cdot 8$ miles.

Felsitic texture. Brown-grey, granular.

M. $77 . \quad$ S. $11^{\circ}$ W. Edd., $38 \cdot 8$ miles.

Granitic texture. Brown, very fine grain.

Light brown, fine grain, black mica.

M. $58 . \quad$ S. $22^{\circ}$ W. Edd., 39 miles.

Granitic texture. The granitoid rocks occur in rather large pebbles, almost small boulders.

Grey, rather coarse, clear felspars, black mica.

Grey, rather fine, clear felspars, black mica.

M. 62 . S. $25^{\circ}$ W. Edd., 46.4 miles.

Felsitic texture. c. Compact, greenish grey, with pink felspars and porphyritic quartz.

d. A somewhat similar rock, more granular, felspars white, some hornblende.

Also, pink, saccharine texture. 
M. 80 . S. $16 \frac{1}{2}^{\circ}$ W. Edd., $48 \cdot 9$ miles.

Granitic texture. Brown-grey, fine-grained, black mica.

Felsitic texture. Light brown-grey, black mica, apparently a variant of above.

All the above granitoid rocks are described from megascopic examination only, and the list is inserted chiefly in order to point out the localities in which this class of material has been found. To adequately deal with all the varieties a great number of sections would have been required, but probably those which have been microscopically examined give a fair general idea of the whole.

\section{SCHORL ROCK.}

Rocks consisting of tourmaline and quartz; placed here, although undoubtedly in a sense metamorphic, on account of their usual association with granite.

\section{6/4a. W. $\frac{1}{4}$ S. Bolt Head, $4 \frac{3}{4}$ miles.}

A rather small pebble.

This rock consists of quartz and tourmaline. Much of the quartz is secondary; in part it forms a mosaic, in parts it extends from original crystals with which its crystal axis corresponds. The primary quartz contains fluid inclusions with bubbles, the bubble in many instances occupying more space than the fluid; these inclusions are very numerous and rather large. The secondary quartz contains few and very small fluid inclusions. Acicular schorl is scattered throughout the slide, sometimes in almost fibrous radial bunches, at others in slender, well-defined prisms, radially or otherwise arranged; there is also some more massive schorl. The colour is chiefly light blue to rich blue, but blue-green occurs, and occasionally olive-brown.

\section{31 . S. $25^{\circ}$ W. Edd., 15 miles.}

A schorl rock of Dartmoor type.

Ground-mass a quartz mosaic. The quartz contains many fluid inclusions, some of which, in addition to a bubble, have also cubic crystals in the fluid. These cubic crystals are, in fact, very common. The slide is crowded with granular tourmaline, chiefly a very dark brown colour, almost opaque, but a few grains are blue-green.

\section{31g.}

Schorl rock. The general ground of a brown shade, an intimate mixture of rather pale brown tourmaline and quartz. Frequent areas of quartz partially invaded by acicular tourmaline. Some cracks are also filled by quartz. The quartz areas all present a mosaic, in which some grains contain many more fluid inclusions with bubbles 
FIG, 1.

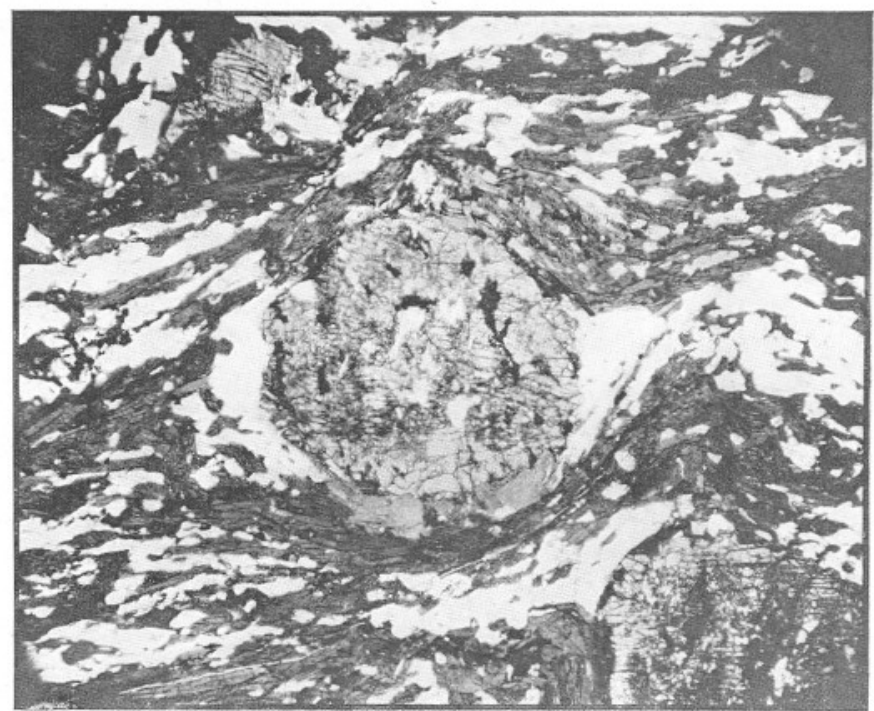

354/1. N.W. by N. (mag.) Fdd., $\frac{1}{2}$ mile.

Hornblende gneiss, with garnets.

Ordinary light. $\times 14 \frac{1}{2}$.

FIG. 2.

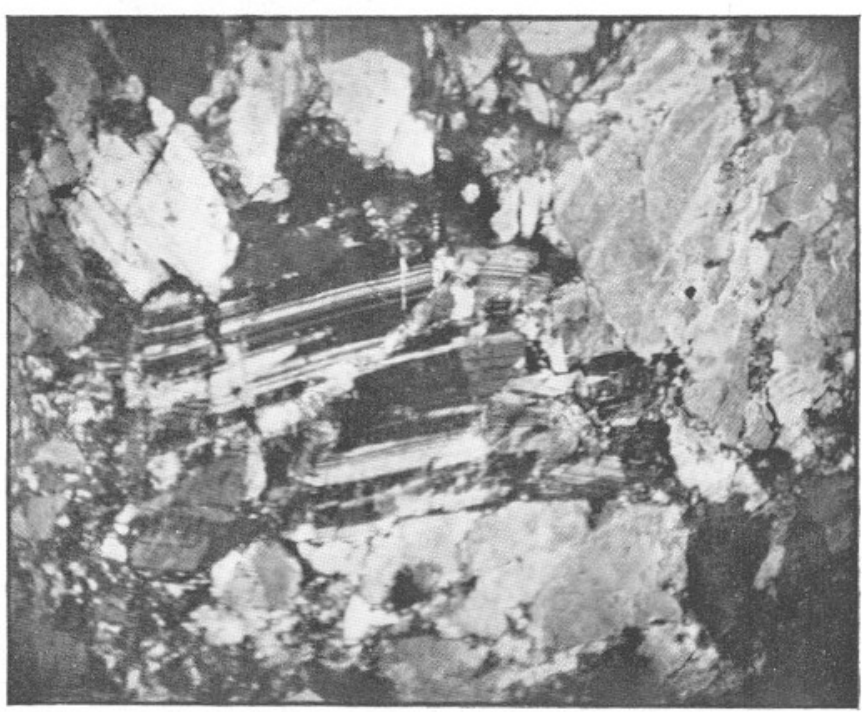

M. 62 a. S. $25^{\circ}$ W. Edd., $46 \cdot 4$ miles.

Crushed plagioclase felspar in chlorite schist.

Crossed nicols. $\times 29$.

To face p. 135. 
than do others. Small cubic crystals are not infrequent in these inclusions.

Schorl rock also occurs at 36 a, S. $54^{\circ}$ W. Edd., $17 \cdot 5$ miles; 72 , S. $23^{\circ}$ W. Edd., 19 miles ; 14 f, $\mathrm{S} .41^{\circ}$ W. Edd., 20 miles.

\section{ANDESITES.}

$354 / 4$ b. $6 \frac{1}{2}$ miles W. from Rame Head.

Strictly speaking a felsite. Red-brown felsitic ground-mass, with porphyritic orthoclase, quartz, and dark mica. One of several pieces here dredged, with every indication of being practically in situ. Is much like the andesitic felsite of Withnoe, but lacks the flow structure sometimes present in the latter. The similarity of the specimens to many, however, which have been collected at Withnoe practically amounts to identity. Thus to the Cawsand mass and the two near Withnoe we have to add another, and a submarine, patch of igneous rock of the New Red Sandstone period. Apparently this exposure is of some considerable area. A conglomerate containing large fragments of this rock was taken in the same dredging.

M. 15 a. S. $27^{\circ}$ W. Edd., $20 \cdot 3$ miles.

Brownish-grey trachytic rock.

Well-marked flow structure. Ground-mass a devitrified glass (palagonite). Some augite developed in rare crystals and crystalline areas. Flakes of very dark brown mica rather frequent. Lines and microdendritic growths of iron ore (?) hematite. Occasional patches of calcite.

M. 15. Also yielded a more red variety of the above.

\section{GNEISS.}

Some latitude must be allowed in any classification which attempts to discriminate Gneiss from Schist in this area. If anything, the writer leans toward identification as the former in doubtful cases.

354/1. N.W. by N. Edd., $\frac{1}{2}$ mile.

A large stone or small boulder, angular with freshly fractured surface. A grey-green foliated rock with plates of brown mica and numerous garnets up to $1.75 \mathrm{~mm}$. in diameter. Quartz fills thin joints at right angles to the planes of foliation. The mica is so developed as to give to the rock an easy cleavage.

The pale-pink garnets are a characteristic feature; these are much cracked, and around them bend the less resisting minerals. There is much blue-green actinolitic hornblende, the blades of which all approximately conform to one direction. Mica is in much less quantity than would appear from the hand specimen; it is intensely pleochroic, from pale straw-colour to dark cinnamon-brown; its occurrence is practically limited to the neighbourhood of the garnets.

NEW SERIES.-VOL. VIII. No. 2. 
Touching and partially enveloping the garnets is a certain amount of chlorite. Water-clear felspar in mosaic form fills all interspaces; it appears to be albite, and inclusions of apatite are frequent. There seem to be some rare fragments of pale brown-augite. (Plate VII, fig. 1.)

\section{4/3f. Hand Deeps.}

A schistose or foliated rock, dark steel-grey in colour, and highly lustrous from the abundance of pale mica. Rare eyes of red felspar occur.

The section does not pass through any of the felspar eyes. There is a distinct banded structure: bands in which hornblende predominates, bands consisting almost entirely of white mica, bands of felspar mosaic. "But in every layer there is some slight admixture of the other minerals. The hornblende is both uralitic and actinolitic with very distinct indigo tint here and there. It is not entirely free from chlorite. The mica appears perfectly fresh and shows no trace of pleochroism. Both hornblende and mica exhibit a parallelism of arrangement. The felspar is apparently albite, quite clear, with apparently a casual grain of quartz. Grains of sphene are not uncommon.

\section{5/1. West side of East Rutts.}

A brown stained schistose or gneissic rock, exhibiting much contortion.

No part of the slide is entirely free from iron stain. Contorted bands of limonite traverse it, and these appear to have been developed at the expense of mica, bleached residual blades of which are associated with it. All the mica is much bent. Parallel with, and touching the limonite, are narrow interrupted bands of calcite. The general ground-mass is a mosaic of slightly stained clear minerals, and apparently consists of albite (?) and quartz in about equal proportions, the quartz showing fluid inclusions with bubbles, and the albite being rather frequently twinned.

\section{36 p. S. $37^{\circ}$ W. Edd., $17 \cdot 5$ miles.}

A mica schist or gneiss, shows clear felspar, some in moderate-sized crystals, and mica which is in general rather silvery but in small patches dark bronze.

There are two orders of felspar, the one represented by slightly clouded crystals of irregular outline and exhibiting signs of crush, the other present in mosaic form. The repeated twinning of plagioclase appears almost constantly in the former, but not at all in the latter. And some few of the larger crystals extinguish differently in different zones, although there is no appearance of zonal structure except 
between crossed nicols. The mosaic in places is of larger and irregular granules, in places of small granules of lenticular form the longer axes of which lie parallel to each other and form lines flowing round the crystals of the first order. The mica conforms in general direction to these same lines, it shows moderately strong pleochroism, and its face colours range from rich cinnamon-brown in basal planes to a rather pale olive-brown in sections perpendicular to these planes. A very little apatite is present.

\section{16 a. S. $29^{\circ}$ W. Edd., 20.9 miles.}

Schistose rock. Dark grey and pale brown, lamination very clearly defined; fissile. Much dark grey mica on joint faces.

Structure schistose. Irregularly bounded felspar areas occasionally associated with quartz form "eyes," around which the other minerals are bent. These felspars are all much clouded; some are thickly set with microlites, but polysynthetic structure is clearly discernible in many instances. Most of the felspars are curiously isolated from their surroundings and have a rounded form, as though due to friction. White mica is abundantly developed, forming streams in which the felspars appear as islands. Mingling with the mica is dull green hornblende in short blades and in grains. There are numerous long patches and irregular areas of quartz mosaic, the quartz containing some apparently fluid inclusions, prismatic microlites, the larger of which are seen to be hornblende, and rather frequent blades of the latter mineral. The mica does not appear to invade the quartz areas. Apatite is fairly plentiful. There is occasional staining by iron oxide, especially between the quartz grains and the blades of mica.

This rock is a gneiss, and has evidently been subjected to extreme pressure.

\section{M. $9 \mathrm{k} . \quad$ S. $31^{\circ}$ W. Edd., $21 \cdot 7$ miles.}

A grey gneiss.

Schistose structure well marked. Somewhat clouded felspars appear to form the only remaining original mineral. These show plagioclase twinning; some have been broken across with the development of a felspar mosaic along the line of fracture. There are two orders of mosaic structure, the one coarser and composed of a very clear mineral, the other much finer and containing minute hornblende and apparently zoisite. For the more part the large felspars are surrounded by this finer material, into which they have the appearance of having been driven. Ilmenite, hornblende, and zoisite mark out the planes of schistosity. The hornblende is almost entirely in minute blades and needles of a bright blue-green. Prisms of apatite are frequent in the 
mosaic. Of this mosaic, which is probably almost all felspar, it should be noted that the coarser part is formed of entirely irregular interlocking granules; in the finer part the granules all appear lenticular, and their longer axes conform to the planes of schistosity.

From M. 9 a coarse gneiss was also noted, and M. $36 \mathrm{q}$ is but a slight variant of M. 36p.

M. 25 c. S. $24^{\circ}$ W. Edd., 23 miles is a coarse gneiss with white opaque felspar and grey-green chlorite.

\section{SCHISTS.}

\section{MICA SCHIST.}

\section{$354 / 3 /$ e. Hand Deeps.}

A mica schist in which micaceous layers greatly contorted and convoluted alternate with granular layers of quartz and garnet. This rock has not been microscopically examined.

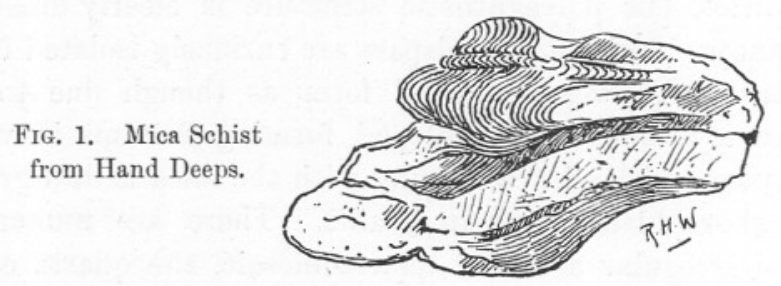

M. 31 . S. $25^{\circ}$ W. Edd., 15 miles.

A grey schist of very fine grain, traversed by rather broad lightercoloured bands.

The section shows a distinctly foliated rock, the lighter parts are a clear quartz mosaic; I can detect no felspar; the quartz shows numerous fluid inclusions, some with very small bubbles. The darker parts appear to consist of a scaly mica of a yellow tint, associated with which is a little limonite and black granular matter which may be carbonaceous.

\section{M. $11 x$. S. $26^{\circ}$ W. Edd., $17 \cdot 8$ miles.}

Micaceous schist, the planes of schistosity well marked by lustrous bronze mica, cleaves very perfectly.

The section shows, in addition to mica, a granular mosaic, which certainly in the main consists of quartz but also contains felspar, which latter can only be detected by its biaxial figure in convergent light. The quartz has, in the larger grains, fluid inclusions with bubbles. The mica is of a rich brown colour, but some few rather well-developed crystals are colourless. The basal sections show numerous acicular microlites, and also very dark brown patches, almost opaque, surrounding small crystals which are apparently zircon. 
M. 9 c. $\quad$ S. $31^{\circ}$ W. Edd., $21 \cdot 7$ miles.

A schistose rock of light brownish-grey colour and rather pearly lustre; small darker spots mark an "eye" structure.

The general body of the rock is crypto-crystalline, polarizing in low tints. Streams of mica in minutest scales are developed in this ground-mass, especially near the "eyes," which largely consist of this mineral associated with a felspar mosaic in which some granules are large enough for identification. The basal planes of the mica follow one general direction throughout the slide. The dark colour of the "eyes" arises from irregular plates, aggregates of an olive-brown substance with moderate double refraction, but this may be somewhat masked by the colour.

M. 43 a. S. $21^{\circ}$ W. Edd., $28 \cdot 8$ miles.

A thin pebble of dark grey schist.

A minutely granular rock, consisting of quartz, felspar probably all plagioclase, white-mica (sericite), epidote (?), chlorite, and traversed by a vein of calcite. Apatite is present in some quantity. The felspar granules freely exhibit the repeated twinning of plagioclase.

M. 20 g. S. $25^{\circ}$ W. Edd., $20 \cdot 5$ miles.

Closely resembles $\mathbf{M}$. 11x, but the mica has a more decidedly bronze lustre. In both these rocks there are stray features of resemblance to the series from the immediate locality of the Eddystone.

M. 31 c. S. $25^{\circ}$ W. Edd., 15 miles.

Rather like a fine-grained granitoid rock, now stained brown by exposure, but fissile from the development of silvery mica along definite planes.

M. 36 c. S. $37^{\circ}$ W. Edd., $17 \cdot 5$ miles.

Largely quartz, but with possibly some felspar, silvery mica chiefly confined to the cleavage planes, which are stained pink with iron oxide. A very fissile rock.

\section{CHLORITE SCHIST.}

Off Stoke Point.

A silvery-green schist, consisting of vivid blue-green chlorite changed here and there to a dull orange, at which places it exhibits a moderate double refraction, and water-clear felspar in which no repeated twins are observable (the section is small). There is also apatite, and much of a granular dusty brown mineral, buff coloured by reflected light, leucoxene.

356/1. 4 to 5 miles S. $\frac{1}{2}$ E. from Prawle Point.

A chlorite schist with bands of quartz one-eighth of an inch in width. 
356/2. 3 miles S.S.E. $\frac{1}{2}$ E. from Prawle Point.

A silvery grey chlorite schist with minutely wrinkled surfaces of chlorite precisely like the shore rocks. Much chlorite.

These last three specimens are practically identical with rocks to be found in situ on shore in the Start Point to Bolt Tail district. None of the specimens show signs of travel or wear.

M. 62 a. S. $25^{\circ}$ W. Edd., $46 \cdot 4$ miles.

A mixture of felspar and quartz, largely the former. Micro-mylonitic structure well developed and some of the felspars greatly deformed. One in especial, with well-marked plagioclase twinning, is much bent in reverse directions, is cracked, and finally at each end passes into mylonite. The slide is full of similar evidence of deformation. As a whole the felspar has a reddish tinge; some portions are crowded with microlites of high double refraction, probably calcite. Calcite is rather freely developed, filling interspaces and cracks. Chlorite plays a similar part, and the two are associated. In places the chlorite is thickly strewn with minute grains and blades of a feebly translucent brown mineral.

If the presence of original felspars is to be the criterion this rock should have been included among the gneisses. (Plate VII, fig. 2.)

HORNBLENDE SCHISTS WITH AUGITE.

$356 / 4 /$ b. W. $\frac{1}{4}$ S. Bolt Head, $4 \frac{3}{4}$ miles.

A very compact dark greenish-grey schist with occasional small specks of pyrites.

The slide looks distinctly patchy, augite areas of brown tint, and granular augite. Much uralitic hornblende, blue in ordinary light, with a faint tinge of green, pleochroism brownish grey to blue-green. This mineral dominates the section. Much calcite, with a tendency to form broad bands. And, filling irregular interspaces, a mosaic of waterclear granules, containing both felspar and quartz. Calcite mingles with this mosaic. A little leucoxene occurs.

\section{80 b. S. $16 \frac{1}{2}^{\circ}$ W. Edd., $48 \cdot 9$ miles.}

Fine-grained dark grey rock; some pyrites.

Structure schistose. Marked in part by veins of secondary quartz in mosaic. The felspar is entirely clouded with decomposition products; it lies irregularly mingled with very pale green fibrous hornblende. The latter has apparently developed at the expense of a pale pink augite, of which a fair quantity remains; in turn the hornblende has here and there given place to chlorite. Irregular grains of a feebly translucent mineral, probably leucoxene, are plentiful, and have a distinct tendency to linear arrangement. 


\section{CALC SCHIST.}

\section{14 r. S. $24^{\circ}$ W. Edd., 20 miles.}

A compact rock with well-marked cleavage, the planes of which are not, however, closely set. Broken across the cleavage, the colour is a warm grey and the texture close and uniform. The cleavage planes show a somewhat pearly lustre and are stained in parts with red oxide of iron. The rock gives distinct effervescence with cold acid: with warm acid effervesces freely; fragments retain their form, however, but from the surface a few small quartz grains are set free.

The section shows numerous clear grains set in granular cement, with which, in places, is much red oxide of iron. Colourless mica (sericite) is rather sparingly developed, being more prominent on the cleavage planes. The clear grains are quartz, with the very rare exception of a felspar, and many show boundaries imposed upon them by the adjacent calcite and dolomite, which freely exhibits the rhombus form of larger or smaller dimensions. The granular cement consists, in fact, almost entirely of minutely crystalline dolomite and calcite, a high power being required to detect the crystal forms. A very large proportion of the quartz grains show secondary enlargement, the secondary quartz having the same crystal axes as the original grain. The boundary between the original and secondary is just such a dark line as occurs when a mineral of greater refractive index is enclosed in a mineral of less. Hair-like microlites are not uncommon in the primary quartz, but none pass over into the marginal secondary growth. In the loose powder obtained by treating this rock in hot acid I found one small crystal of tourmaline.

The fact that the rock retains its form after treatment with hot acid shows that neither the iron nor the dolomite are necessary cements, the secondary quartz being in itself sufficient.

Presumedly it is best to call the specimen a calcschist.

\section{SERPENTINE.}

\section{M. $24 \mathrm{~h}$.}

A small jet-black pebble with very smooth surface.

The section shows yellowish-green serpentine with "lattice" structure, traversed by roughly parallel streams of dense black material, which also occurs irregularly in cracks of varying direction, and more or less densely diffused in certain parts of the slide over areas which appear reminiscent of the original structure of the rock. The serpentine varies considerably in its depth of shade. At one point it is blue-green around the margin of a clear mineral, which appears possibly to be a plagioclase felspar. 
The serpentine, some of which is colourless, splits up under crossed nicols into doubly refracting bands and isotropic portions.

The association of felspar with a massive serpentine is rare, but Professor Bonney has recorded an instance from the Lizard district.

This specimen acquires some value, despite its small size, since in HuNT's series there occurs a serpentine boulder, H. 6, of 5 cwt.

\section{QUARTZITES.}

A number of quartzites, very similar to some in the Budleigh pebble-bed, have been dredged from a great many stations. Up to the present no fossils have been found in them. These rocks vary in colour, being purple, red, light red, buff, grey and white, and are associated with very hard grits which have not been sufficiently examined.

M. 80 . S. $16 \frac{1}{2}^{\circ}$ W. Edd., $48 \cdot 9$ miles.

Purple quartzite, very compact in structure. Quartz grains, subangular and of very uniform size, fluid enclosures common. The cementing material silica with much iron oxide; this cement appears to be minutely granular. An occasional quartz grain shows hair-like microlites.

This may be taken as a type. Other Purple Quartzites were dredged at Stations M. 31 , M. 36, M. 13, M. 35, M. 27, M. 26, M. 34, M. 29, M. 14, M. 20 , M. 9 , M. 40 , M. 22 , M. 25 , M. 43 , M. 50, M. 67 , and M. 80 .

Red quartzites from M. 11, M. 72.

Light red quartzites from M. 13., M. 30.

Buff quartzites from M. 34, M. 20, M. 22, M. 41, M. 43.

White quartzite from M. 21.

M. 11f. S. $26^{\circ}$ W. Edd., $17 \cdot 8$ miles.

A grey grit.

A little mica appears in the section. The rock is practically a quartzite.

\section{SEDIMENTARY ROCKS.}

Under the heading of sedimentary rocks have been included all altered varieties, except such as may possibly have been fully metamorphosed to schists and quartzites.

CARBONIFEROUS AND EARLIER.

SANDSTONES AND GRITS.

$354 / 4 \mathrm{k}$. $6 \frac{1}{2}$ miles W. from Rame Head.

A red micaceous grit, probably Devonian.

M. 9 b. $\quad$ S. $31^{\circ}$ W. Edd., $21 \cdot 7$ miles.

A light brown sandstone of flaggy structure, bedding marked by slight variations of tint. Possibly Devonian. 
Fig. 1.

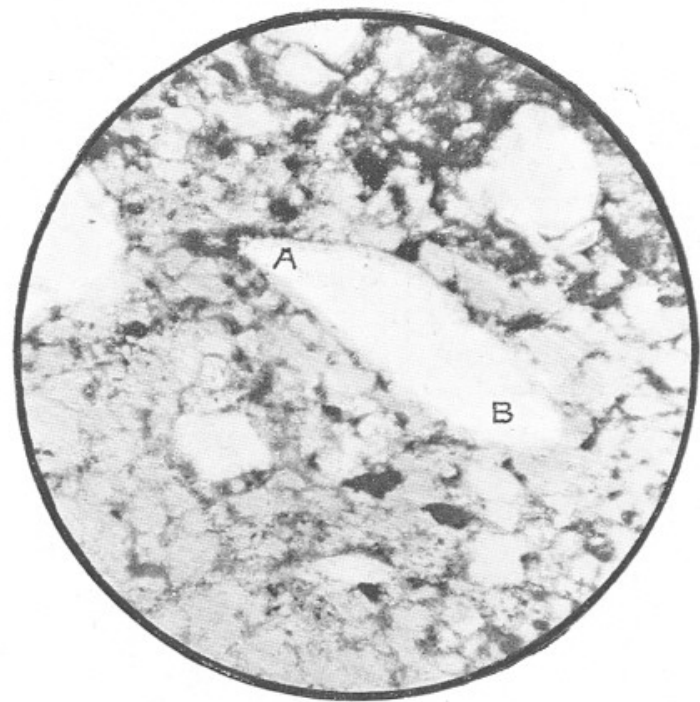

M. 9 d. $\quad$ S. $31^{\circ}$ W. Edd., $21 \cdot 7$ miles.

Grit, showing large grain, A-B.

Ordinary light. $\times 29$.

F1G, 2.

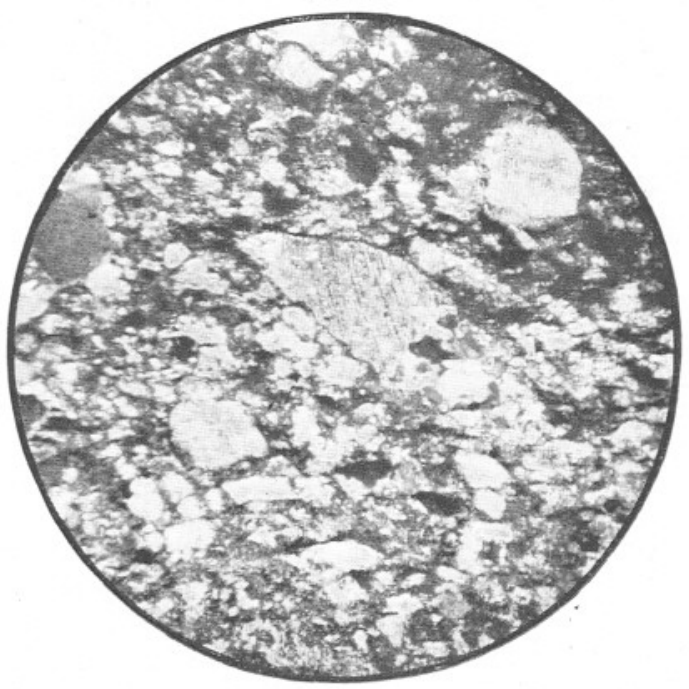

M. 9d. $\quad$ S. $31^{\circ}$ W. Edd., $21 \cdot 7$ miles.

Grit, showing compound structure of grain ; at end A striated felspar, at end B quartz mosaic.

Crossed nicols. $\times 29$. 
M. 9d.

A rather light grey rock, which appears to be a compact and very fine-grained grit; looks much like many grits of the Devonian age.

The microscope confirms preliminary examination; this rock is a grit of close texture. A considerable proportion of the granules are felspar, many showing repeated twins.

A number of the grains prove to be of compound structure, and are portions of quartz and felspar mosaics from some original schist or gneiss. Further than this, three of the larger grains are compounded of portions of felspars with bent striation and portions of quartz mosaic, being, in fact, derived microscopic specimens of gneiss. As bearing on the age of the rocks which have supplied the fragments. this slide is distinctly interesting. The interstitial matter largely consists of a rather pale chlorite in which occur rare blades of pale mica, There is some ilmenite, apparently detrital. (Plate VIII, figs. 1 and 2 )

\section{11f. S. $26^{\circ}$ W. Edd., $17 \cdot 8$ miles.}

A fine grey grit slightly browned by exposure. Much like last in general appearance, and may well be of Devonian formation, already included as quartzite, the cement being apparently silica. The grains are sub-angular and include a few felspars. There are rather numerous grains of sphene, some irregular, some of the characteristic lozenge shape, all apparently derived.

Grits, not microscopically examined, were also taken at M. 31, M. 27, M. 26 , M. 14 , M. 20 , M. 16 , M. 9 , M. 40 , M. 19 , M. 41 , M. 77 , and M. 80.

\section{SLATES.}

Unaltered slate was scarce, as might be expected from the fact that it would usually be associated with much harder material, and probably be soon destroyed.

M. 77a. S. $11^{\circ}$ W. Edd., 38.8 miles.

Dark compact shale, a clay slate.

Under the microscope appears built up of minute grains of high double refraction. There are frequent traces of minute organisms, some possibly foraminifera. Some shell fragments still consist of carbonate of lime, and numerous forms of circular section are infilled with calcite.

M. 39. S. $38^{\circ}$ W. Edd., 21.9 miles.

A decomposed slate.

\section{ALTERED SLATES.}

354/4j. $6 \frac{1}{2}$ miles W. from Rame Head.

A slate of Devonian type, evidently altered by the proximity of the andesite dyke which here occurs. 


\section{14 j. $\quad$ S. $24^{\circ}$ W. Edd., 20 miles.}

Almost black, a very compact rock with sub-conchoidal fracture, and lustre somewhat like a quartzite. The worn surface shows rather minute banded structure.

The same banded structure shows in section when examined by the unaided eye, but is less prominent under the microscope; this is a sedimentary rock altered by contact metamorphism. The general ground-mass is a crypto-crystalline substance, rising to a minute mosaic here and there, and probably having a complex mineral composition. Felspar almost certainly plays an important part. In this there occur small grey-clouded areas, presenting sections which are chiefly of somewhat ill-defined rhombus shape, and which in certain positions completely extinguish. One such area has a portion clear of dusty products, and this shows high double refraction in a bright and pure colour; other similar instances occur. The dusty material shows a tendency to arrange itself in zones and crosses, and from examination of a great number of these imperfect crystals there can be no doubt that the rock is crowded with andalusite in a condition bordering on the chiastolite form. For the rest, there is much small brown mica, and titanic iron ore, mostly in very small grains, is quite plentiful. Such a rock might easily arise from the metamorphism of a Devonian or Carboniferous slate by contact with a large boss of igneous material.

Altered slates, having the appearance of being baked by proximity to igneous rock, were also taken at the following stations, but have not been examined microscopically.

M. 11, M. 34, M. 72, M. 14, M. 15, M. 21 (common), M. 24 (very common), M. 17, M. 18.

\section{LIMESTONE.}

\section{26 b. S. $20^{\circ}$ W. Edd., $18 \cdot 4$ miles.}

A blue-grey limestone, veined and mottled with lighter calcite, much like some of the South Devon middle Devonian series. Consists almost entirely of irregular interosculating calcite patches, traversed by cracks filled with clear calcite. The calcite forms give indication of former organic remains, and at three places undoubted sections of madrepore occur. Around and between the boundaries of some of the calcite areas are very irregular and much folded lines of a granular black substance, apparently carbonaceous.

\section{NEW RED SANDSTONE. CONGLOMERATE.}

$354 / 3$ b. Hand Deeps.

A red conglomerate, certainly of the New Red Sandstone period. Among the derived constituents are quartz grains of some size 
showing mosaic structure and containing fluid inclusions with bubbles. Other grains of felspar mosaic precisely similar to that occurring in the neighbouring schists and gneisses. Blades of mica that may have been similarly derived. Quartzites, and fragments of highly cleaved slates, or very fine-grained schists.

Calcite or dolomite, probably the latter, is very prominent, filling the interspaces.

$354 / 4$ b. $6 \frac{1}{2}$ miles W. from Rame Head.

Conglomerate with fragments of andesite.

\section{SANDSTONE.}

\section{4/3c. Hand Deeps.}

A coarse, red, micaceous sandstone.

354/2a. S.W. Edd., 2 miles.

Variegated sandstone, fine texture, red and grey.

$354 / 2 \mathrm{~b}$.

Buff sandstone, almost salmon coloured.

$354 / 2$ c.

Fine-grained compact red marly sandstone, sub-jaspideous.

M. 31 . S. $25^{\circ}$ W. Edd., 15 miles.

Red sandstone and buff sandstone.

M. 32 . S. $25^{\circ}$ W. Edd., $16 \cdot 3$ miles.

Red sandstone and yellow sandstone.

M. 10 . S. $26^{\circ}$ W. Edd., 178 miles.

Red sandstone.

M. 33 . S. $25^{\circ}$ W. Edd., $17 \cdot 5$ miles.

Red sandstone.

M. 34 . S. $28^{\circ}$ W. Edd., 18.5 miles.

Variegated, red and grey.

M. 27. S. $19^{\circ}$ W. Edd., 18.3 miles.

Red sandstone and buff sandstone.

M. 26. S. $20^{\circ}$ W. Edd., 18.4 miles.

Red sandstone.

M. 40. S. $38^{\circ}$ W. Edd., 21.7 miles. Variegated, red and grey.

M. 17. S. $28^{\circ}$ W. Edd., $23 \cdot 3$ miles. Red sandstone.

M. 19 . S. $28^{\circ}$ W. Edd., $23 \cdot 3$ miles. Red sandstone in large angular blocks.

M. 18. S. $29^{\circ}$ W. Edd., 23.4 miles. Red sandstone. 


\section{21 g. S. $25^{\circ}$ W. Edd., $21 \cdot 2$ miles.}

(Not inserted in the above series because structurally different; all the above are of ordinary type.)

A compact rock with granular fracture; the granules vary from buff to a light brown with a tinge of Indian red. The rock has been bored by molluses.

A sandstone cemented by crystalline calcite, dolomite, or in the alternative a very sandy crystalline limestone. The quartz grains well rounded with numerous, and some large, fluid inclusions. One grain which proves to be part of a quartz mosaic contains a fragment of rich brown mica. Yet another grain contains brown mica, and many have acicular microlites, possibly apatite. Considerably less numerous than the quartzes are felspar grains, both orthoclase and plagioclase. There are numerous fragments of a brown rock, apparently a palagonite, containing some crystals, including mica. The rhombs of dolomite are clearly marked out by concentric bands of dark brown inclusions, grains, and microlites, which tend to form radial bunches. In some cases the centre of a rhomb is completely darkened.

\section{MARLS.}

Under this heading are included hard marly limestones, those more exceptional forms from the Trias which are calculated to resist abrasion; with them is a smaller percentage of the true friable marl.

\section{34 b. S. $28^{\circ}$ W. Edd., $18 \cdot 5$ miles.}

A dark red pebble, with smooth surface, much bored by molluscs. A cut surface shows very compact rock, the red colour of which is slightly mottled by a lighter shade. In the section this mottling is much more prominent. The rock is minutely granular, the mineral being probably a mixture of calcite and dolomite. There are also small angular fragments of quartz, and apparently some fibres of gypsum. Some of the borings have been infilled with secondary sandstone having calcareous cement. The stone is a very hard marl.

\section{IM. 9f. S. $31^{\circ}$ W. Edd., $21 \cdot 7$ miles.}

A fine-grained red marl.

Much very fine sand, with some larger quartz grains. The colour not uniformly distributed but mottled with grey. Many of the grains appear to be crystalline calcite or dolomite.

M. 31 . S. $25^{\circ}$ W. Edd., 15 miles.

Soft variegated marl, red and green.

M. 36 . S. $37^{\circ}$ W. Edd., $17 \cdot 5$ miles.

Hard chocolate-coloured marl. 
M. $11 . \quad$ S. $26^{\circ}$ W. Edd., $17 \cdot 8$ miles.

Hard chocolate-coloured marl.

M. 12 . S. $26^{\circ}$ W. Edd., $17 \cdot 8$ miles.

Hard chocolate-coloured marl.

M. $35 . \quad$ S. $32^{\circ}$ W. Edd., 18 miles.

Hard chocolate-coloured marl.

M. 34 . S. $28^{\circ}$ W. Edd., $18 \cdot 5$ miles.

Hard chocolate-coloured marl.

M. 14 . S. $24^{\circ}$ W. Edd., 20 miles.

Hard chocolate-coloured marl.

M. 15 . S. $27^{\circ}$ W. Edd., $20 \cdot 3$ miles.

Pale red, rather soft marl.

M. 20 . S. $25^{\circ}$ W. Edd., 20.5 miles.

Hard chocolate-coloured marl.

M. 24 . S. $24^{\circ}$ W. Edd., $22 \cdot 5$ miles

Hard chocolate-coloured marl.

\section{LIMESTONES.}

The following dolomitic limestones would appear to belong to the New Red Sandstone formation.

M. 34d. S. $28^{\circ}$ W. Edd., $18 \cdot 5$ miles.

A rather small brown-grey pebble, much bored by saxicava. Freshly broken surface is pale brown, and shows somewhat granular, very uniform, texture.

The section, examined by the unaided eye, suggests a slightly marked banded structure. The matrix of the rock is a fairly pure crypto-crystalline calcite and dolomite, and minute zoned rhomboids of the latter mineral occur sparsely. But it is so closely set with small sand grains that it might almost be described as a sandstone with calcareous cement. Most of these clear grains are probably quartz, but some show the repeated twinning of plagioclase felspar. A little brown mica is to be found, and rather numerous rich brown and black specks, which may be rutile. There are also many pale olive patches, distinctly larger than the other granular constituents, somewhat ill defined in outline and apparently calcareous. The calcareous ground-mass has here and there a yellowish-brown tint.

M. $35 \mathrm{e} . \quad$ S. $32^{\circ}$ W. Edd., 18 miles.

A very similar rock to the last described.

M. 21 a. S. $25^{\circ}$ W. Edd., $21 \cdot 2$ miles.

A compact horny-textured rock distinctly hard, but bored by 
molluscs, etc. Colour of broken surface brown with a shade of purple, and buff. Weathered surface an uniform light brown.

A granular crystalline limestone, stained by iron in patches and lines. Apparently it has always contained some free spaces which are lined with larger crystal grains. Occasional almost complete rhombs of dolomite of small size occur. There are slight streams of a pale brown mineral of low double refraction; and scoriaceous looking inclusions of rich brown rock, containing small quartzes; these are the more aluminous parts of the rock.

\section{PASSAGE BEDS-TRIAS TO RHAETIC.}

\section{29 a. $\quad$ S. $14^{\circ}$ W. Edd., $19 \cdot 8$ miles.}

A coarse, open-textured marl or marly limestone, drab coloured. The section shows widely varying colour and texture, giving at first sight the effect of a detrital rock with many derived fragments. That there are fragments of other marly limestones does indeed appear to be the fact; certain textures associated with definite colours, and with mineral forms not found generally distributed throughout the slide, are located in areas with well or less clearly defined boundaries. On the other hand, the same yellow iron stain which marks some of these areas runs irregularly across the section in a contorted and divided stream and is always associated with a finer ground-mass than the average.

In the general body of the rock, besides much granular crystalline calcite, occur small spheroids of a clear mineral, which consist of fibres radially arranged, and are also marked by a slight concentric zoning. One long vein shows the same structure, and its outline is botroidal. This mineral is soluble in $\mathrm{HCl}$. There is a fair amount of dark material, which may be carbonaceous. Not infrequent quartz grains. And in the rather ill-defined orange-brown inclusions (if inclusions they are) a fibrous mineral in single blades showing a double refraction considerably less than that of mica; none of this is to be found in the residue after solution in acid, and it may be gypsum. One piece of certain mica is visible, with pleochroism from colourless to cinnamonbrown. The residue after solution in acid consists chiefly of a rich olive-brown isotropic matter in flocculent form.

\section{M. $29 \mathrm{~b}$.}

Compact, smooth, and fine-textured marl in thin slabs, can be marked by thumb-nail, drab coloured. The section shows very minute grains of calcite, and some brown fragments which may once have been mica.

\section{29c.}

Angular fragment of stone-coloured marl, rather coarser than last, but still fine-grained and compact, just harder than the thumb-nail. 


\section{29d.}

Much like last, but has a greenish tinge.

M. $29 \mathrm{e}$.

Like last, but harder and greener.

M. $29 f$.

Like last, but considerably softer, and greener still with patches of bright decided colour. Micaceous.

M. $29 \mathrm{~g}$.

Green marl and drab-brown marl as above in narrow alternate bands.

M. $29 \mathrm{~h}$.

A layer of coarse grey marl and one of fine-grained drab-brown marl.

The series M. 29a. to M. $29 \mathrm{~h}$. inclusive indicates a locality occupied by soft marls of varying texture and colour, associated in one and the same formation in layers of varying thickness, the alternations being frequent and repeated.

\section{RHAETIC AND LIAS.}

\section{LIMESTONE AND SHALE.}

Most of these limestones contain argillaceous matter; some, however, appear to resemble the White Lias; in the absence of field work it is not well to attempt to do other than group Rhaetic and Liassic together.

OFF LYME REGIS-in situ.

This type rock is frequently dredged off Lyme Regis. The specimen shows coral fragments, including Gonioseris. For the rest it is a rough, somewhat sandy limestone, inclined toward a marl. A great deal of brown and black matter occurs in granular form. Obviously a Lias Limestone.

M. 12 a. S. $26^{\circ}$ W. Edd., $17 \cdot 8$ miles.

Drab-coloured stone, fine in grain. The section shows crystalline granular structure with no visible organisms.

M. 30 a. S. $21^{\circ}$ W. Edd., $21 \cdot 5$ miles.

Darkish limestone, rather brown than buff. Minutely crystalline granular. Traces of organisms; grains and slight micro-dendritic growths of iron oxide.

M. 53a. S. $22^{\circ}$ W. Edd., $32 \cdot 2$ miles.

A light brown slabby rock, bored by molluses. A closely-cleaved, highly-calcareous shale. Corresponds to the "paper shales." Distinctly marly. The section shows occasional aggregates of crystalline calcite. The chief part of the rock is a minutely granular pale brown 
mixture, with mottling of rich orange-brown, less granular, substance, and grains and short irregular lines of an almost opaque dark brown. No undoubted organic remains.

\section{53b.}

A light brown rock, a harder variety of the preceding, contains calcite veins, and one joint-face shows well-developed crystals. The laminæ of this rock are alternately of closer and of more open texture.

The section is made in one of the harder layers and corresponds with 53a, except that it is lighter in general shade and the orangebrown portions are much less in proportion to the whole.

\section{53c.}

Drab-coloured compact rock in slabs, one face of which is usually obviously a joint surface recently broken, and one face much bored, probably by annelids. The section shows a pale brown rock wholly but minutely granular, almost entirely calcite, with an occasional narrow vein of clear calcite, and small scattered brown and black granules. No trace of organisms. This forms the last of a series of which $53 \mathrm{a}$ and $\mathbf{5 3 \mathrm { b }}$ are the first members.

\section{56 a. S. $25^{\circ}$ W. Edd., $34 \cdot 3$ miles.}

A dull brown limestone of light shade.

Contains numerous fragments of shells and rather frequent echinoderm spines, but no foraminifera.

M. 44 . S. $17^{\circ}$ W. Edd., $29 \cdot 8$, miles.

Buff limestone, apparently liassic.

\section{CRETACEOUS.}

\section{CHALK.}

A very hard, yellow, or cream-coloured, chalk is of frequent occurrence; generally the exterior of the pebble is brown, and this colour extends some slight depth into the stone, getting less in intensity until it fades into the yellow or cream-colour. Unless the stone happens to be much bored it usually requires a considerable blow to break it.

\section{26 a. S. $20^{\circ}$ W. Edd., $18 \cdot 4$ miles.}

Hard, cream-coloured chalk. Minutely granular texture. Crowded with small organisms. Many good sections of small foraminifera. Fragments of larger shells frequent. Some of the foraminifera infilled with a yellow-orange substance. Several textularia. Fragments of nodosaria, and some rotaline forms and globigerina. 
Fig. 1.

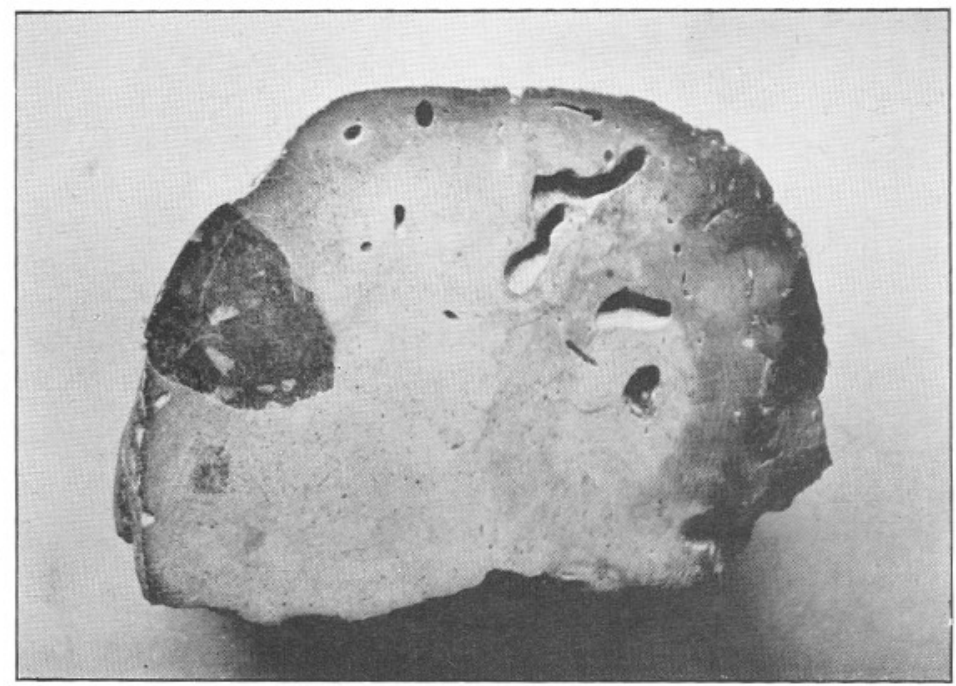

M. 14 a. $\quad$ S. $24^{\circ}$ W. Edd., $20^{\prime}$ miles.

Hard yellow chalk, surface finely ground but not polished. Derived inclusion on left. $\times 1 \frac{1}{2}$.

FIG. 2.

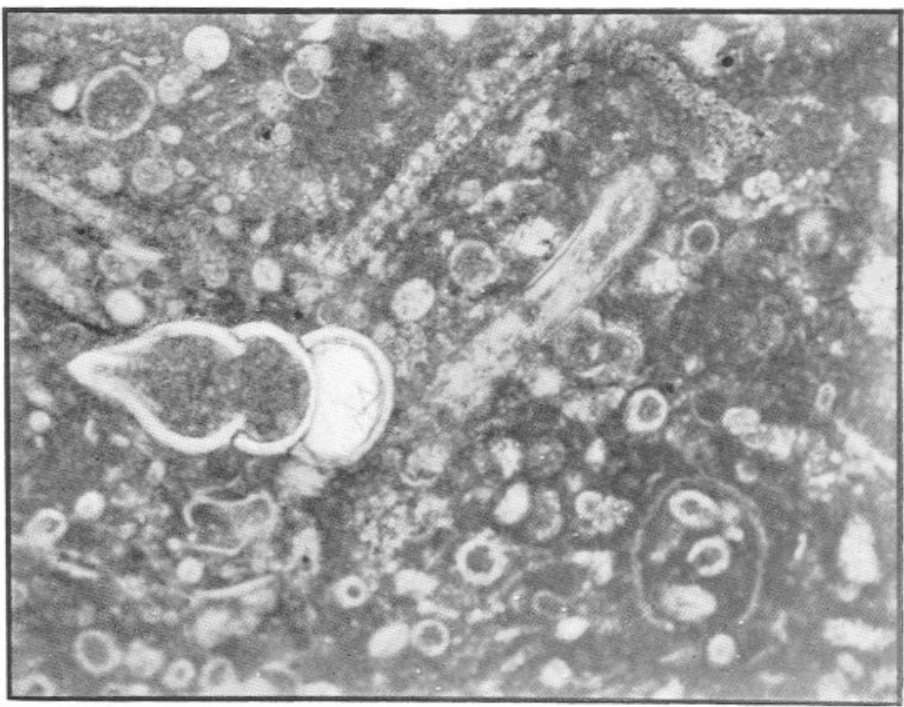

M. 14 a. S. $24^{\circ}$ W. Edd., 20 miles.

Hard yellow chalk.

Ordinary light. $\times 97 \frac{1}{2}$. 
M. 72a. S. $23^{\circ}$ W. Edd., 19 miles.

Hard, cream-coloured chalk.

Texture minutely granular. Crowded with the remains of small organisms, and with shell fragments, etc.

\section{M. $72 b$.}

Hard yellow chalk. Shell fragments, small foraminifera, etc.

\section{21c. S. $25^{\circ}$ W. Edd., $21 \cdot 2$ miles.}

Hard yellow chalk. Crowded with foraminifera. There is a comparatively large circle of calcite $\left(\frac{1}{2} \mathrm{~mm}\right.$.) having radial structure, apparently the cross section of a cylinder, also shell fragments.

\section{14a. S. $24^{\circ}$ W. Edd., 20 miles.}

Should have preceded M. 21c, but placed last, because in some ways typical of the whole series.

A fair-sized pebble, some three inches in length, orange-brown on the outside, within distinctly yellow for an average depth of about $7 \mathrm{~mm}$., then cream-coloured with small lighter patches. A somewhat irregularly bounded area on the surface is a darker brown and more compact than the rest, it is harder and stands slightly above the general level. Before the pebble was broken this measured over $30 \mathrm{~mm}$. by $13 \mathrm{~mm}$. On breaking the stone it was seen to be an inclusion extending $14 \mathrm{~mm}$. inwards. This inclusion, viewed in crosssection, is green around the margin where it is in contact with the cream-coloured rock, and red in the interior and on its outside face. It has small curved cream-coloured markings, the largest $4 \mathrm{~mm}$. by $1 \mathrm{~mm}$, and in grinding down a section these markings were seen to all communicate with the original outer face of the inclusion; they are obviously borings made by some animal and have been infilled with chalk of the same character as the body of the pebble. This is the only specimen in which such a fragment has been observed, but perhaps closer inspection would discover more among the samples.

The section was cut through inclusion and general mass alike; it bears out in all respects the above description. There is a considerable similarity between the chalks forming the included fragment and the body of the pebble, but in the latter there are possibly more shell fragments; foraminifera are exceedingly numerous in both, and grains of glauconite are present in both. The cream-coloured rock has some considerable areas of calcite in interlocked crystalline grains; these are, however, infrequent. The whiter patches in the cream-coloured rock appear to be denser, to have fewer, although still very many, foraminifera, and smaller shell fragments, but there is no divisional line between the two. The foraminifera include Globigerina, Textularia, 
Bolivina, Cristellaria, and Lagena. There are occasional black and dark brown specks. In all except its hardness the rock is distinctly a chalk. (Plate IX, figs. 1 and 2.)

Mr. D. J. Matthews has kindly made an analysis of a portion of the specimen above described, and returns :-

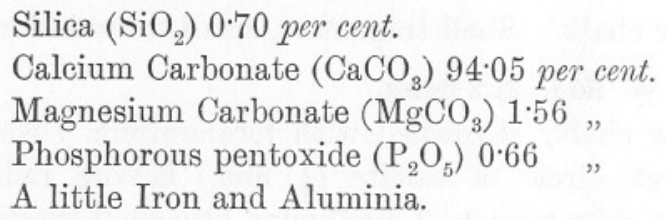

Alkalies not tested for.

From the above it will be seen that the rock is both phosphatic and dolomitic.

Hard Yellow Chall was also taken at the following stations, among others. The list is not quite complete:-

M. 31 , M. 36, M. 33, M. 35, M. 15, M. 25, M. 17, M. 41, M. 58, and M. 67. FLINT.

Flint is quite the commonest rock if the whole area covered by the dredgings is considered. It would be difficult to assert positively that it is anywhere entirely absent from the stony grounds. A. 90 , about four miles toward Plymouth from the Eddystone, is all Devonian, but this was on a sandy ground.

Many of the flints are very unlike, in external appearance, any usually seen on land. ${ }^{1}$ The unaltered mineral is very frequently black, but occurs only in the heart of the pebbles. A solvent action, not necessarily entirely marine, has removed a portion of the silica for some depth from the surface of the stone, and has left a white coherent gritty substance, which is sometimes soft enough to mark on a blackboard, sometimes quite hard. The progress of this alteration can frequently be traced in the section of a broken stone. Pebbles of some inches in thickness are often so far affected that a mere remnant, a patch of perhaps half an inch diameter, will be left in the centre to show what the former condition was. In some even of the large pebbles no unaltered flint remains. It seemed desirable to ascertain what proportion of the original mineral has been removed by this solution, and as an approximation the following method was adopted: M. 15. A piece of thoroughly altered flint, from a stone which showed some remnant of black flint

\footnotetext{
1 Exceptionally, as, for instance, on Hardown Hill and Annis Knob, near Lyme Regis, chert and black Upper Chalk flint are found in much the condition here described, but the presence of carbonate of lime has not been reported, although probably existing much as in these specimens.
} 


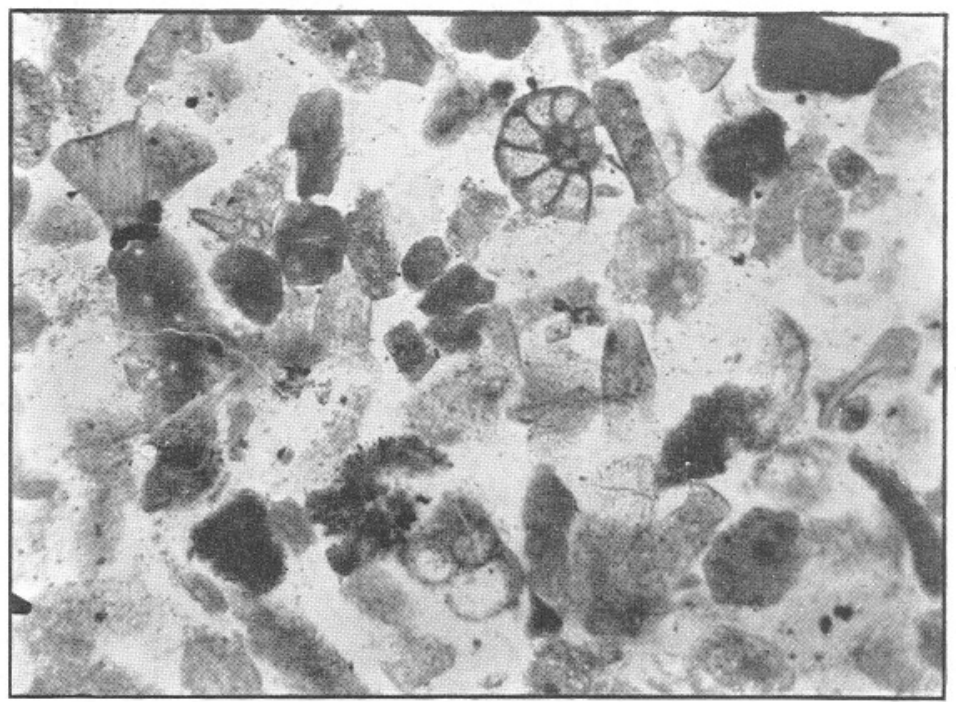

M. 62 b. S. $25^{\circ}$ W. Edd., $46 \cdot 4$ miles.

Decomposed black flint.

Ordinary light. $\times 97 \frac{1}{2}$.

FIG. 2.

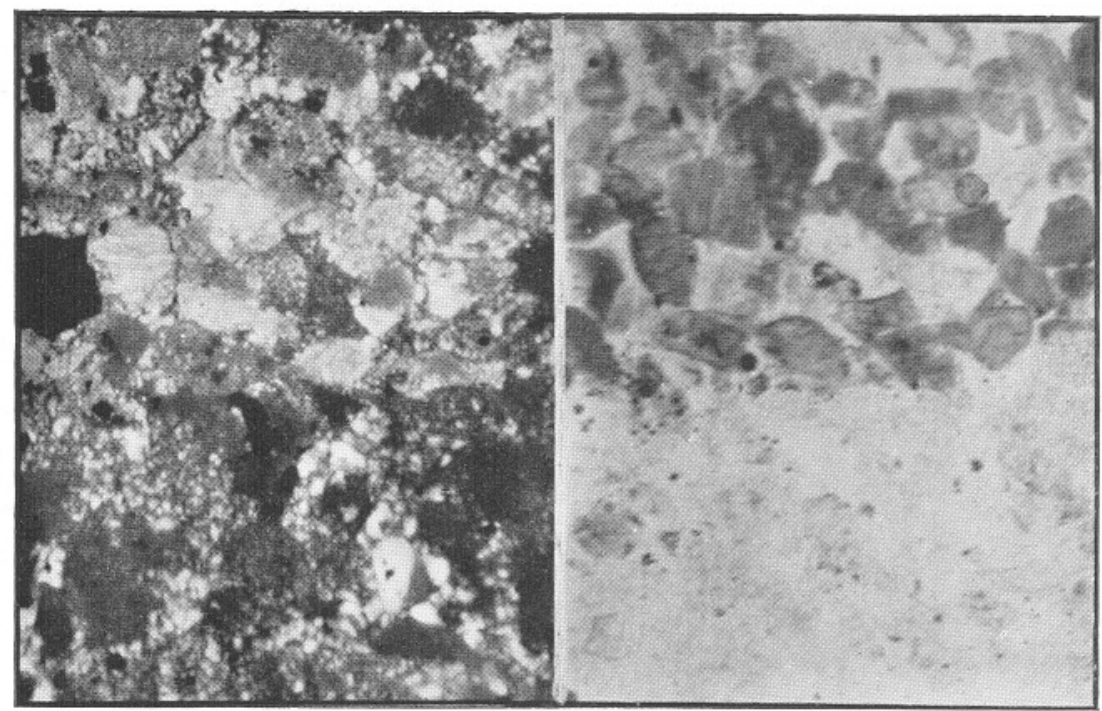

M. 62 b. $\quad$ s. $25^{\circ}$ W. Edd., 46.4 miles.

Decomposed black flint, the lower half of plate represents portion of slide treated with acid.

Crossed nicols, $\times 97 \frac{1}{2}$.

Shell fragments dissolved away from lower half.

Ordinary light. $\times 97 \frac{1}{2}$.

Shell fragments dissolved away from lower half.

To face p. 153. 
at the centre, when dried weighed 51 grains; it was boiled in water for twenty minutes, allowed to remain in the same water until cold, when it was taken out, wiped, and found to weigh $62 \frac{1}{2}$ grains. The specific gravity of the remaining mineral was ascertained to be about 2.56 . If we assume that all the lost material was chalcedonic silica we have to multiply the weight of water absorbed, $11 \frac{1}{2}$ grains, by the specific gravity of chalcedony, say, $2 \cdot 3$, in order to ascertain the loss of the original rock by solution; this gives us about $26 \frac{1}{2}$ grains or somewhat over $33 \%$ of the mass of the original flint. From the fact that the specific gravity of the residue is less than that of quartz, although some calcite also occurs in the rock, it may be assumed that not all the silica yet remaining is crystalline.

These porous altered flints effervesce, some more freely than others, on treatment with acid, but maintain their outward form. The same specimen on which the above determinations were made lost $3 \frac{1}{2}$ grains in weight after prolonged stay in dilute acid. (This loss includes a very small amount of silica and the merest trace of iron.) It would thus appear that the unaltered rock had contained at least $4 \%$ of soluble carbonate. In some instances this is certainly exceeded.

\section{M. $62 \mathrm{~b}$. S. $25^{\circ}$ W. Edd., $46 \cdot 4$ miles.}

This specimen was selected for especial microscopic examination; it is a somewhat chert-like black flint, the outer portion altered as above described. The first section was made from the black part of the pebble, and shows the flint to be nothing more than a silicified chalk. Foraminifera and shell fragments, all still carbonate of lime, crowd the slide, and there are occasional quartz grains and some of glauconite. The matrix is partly crypto-crystalline, and so intimately is the crystalline mixed with the isotropic that practically all the silica ground-mass gives some reaction with polarised light. A second slide, cut from the decomposed part of the rock, shows a cryptocrystalline ground-mass of silica crowded with forms in calcite after organic matter. Foraminifera quite numerous, the chamber walls well defined, but the original structure mainly, if not entirely, replaced by granular calcite. An occasional fragment of some larger shell (molluscan) appears to have retained pretty well its original structure. Glauconite grains occur freely, and some of the foraminifera are infilled with this material.

Finally, to remove any possible ambiguity as to the presence of carbonate of lime, a third section was prepared, also from the decomposed portion. After this had been ground down to the requisite transparency one-half of it was varnished with Canada balsam, and the whole section dipped in dilute acid; a brisk but brief effervescence 
followed. The slide now shows a clear-cut boundary; on the side which was varnished the foraminifera and shell fragments remain, on the other side they have vanished, leaving absolute vacancies. The crypto-crystalline silica is identical in character on either hand. The included quartz grains, which occupy the whole thickness of the slide, polarise in higher colours than the silica of the ground-mass, which is in too minute form to extend through the whole depth.

One interesting point is that the chalk thus converted into flint had not the same original structure as the yellow chalks described previously. (Plate X, figs. 1 and 2.)

The following further specimens were microscopically examined.

M. 15 b. S. $27^{\circ}$ W. Edd., $20 \cdot 3$ miles.

Decomposed flint. Lime not so common except in parts. There are instances of foraminiferal shell entirely replaced by silica. These are best seen by polarised light. In places the grain of the silica in the ground-mass becomes comparatively coarse.

\section{M. $9 \mathrm{~h} . \quad$ S. $31^{\circ}$ W. Edd., $21 \cdot 7$ miles.}

Black cherty flint, with small light markings. The exterior reduced to a white loose-textured substance with minute brown spots. The varying resistance of the flint to decomposition is to be seen where the extreme outer surface has been chipped off, and small patches of almost unaltered rock are visible.

Shows the crypto-crystalline structure of the ground-mass very well. Much like other sections of the same material, except that the calcite fragments are larger, and there are iron-stained areas.

\section{18 b. S. $29^{\circ}$ W. Edd., $23 \cdot 4$ miles.}

Decomposed flint. Hydrozoa and shell fragments, mainly in calcite, but some wholly replaced by silica of coarser texture than groundmass. At one place slight dendritic growth of iron oxide.

Flint is present in greater or less quantity in every sample which yields pebbles or stones. Without actual count an approximate estimate of the proportion of flint to the whole sample has been made in most cases with the following results:-

\section{A. 105. S.S.W. Bolt Head, 1 mile.}

Flint in gravel $13 \%$.

A. 106. S. Bolt Head, 2 miles.

Flint in gravel $40 \%$.

M. 31. Flint two-thirds of whole.

M. 32. Thirty-seven pebbles, of which twenty are flint.

M. 36. Nine-tenths flint.

M. 10. Nine-tenths flint. 
M. 33. Flint predominant.

M. 11. Nearly half flint.

M. 12. Three-quarters flint.

M. 13. About same as IM. 12.

M. 35. Two-thirds flint.

M. 27. Much flint.

M. 26. Flint very plentiful.

M. 34. Over seven-eighths flint.

M. 72. Half flint.

IM. 29. Some flints.

M. 14. Much flint.

M. 15. Three-quarters flint.

M. 20. Two-thirds flint.

M. 16. One-third flint.

M. 21. Half flint.

M. 30. Twenty pebbles, of which fourteen are flint.

M. 9. Nearly half flint.

M. 40. A little flint.

M. 22. Half flint.

M. 39. About half flint.

M. 24. About two-thirds flint.

M. 25. Almost entirely flint.

M. 17. Flint (no note of quantity).

M. 19. Very little flint.

M. 18. One-third flint.

M. 41. One-half large flints.

M. 43. Nine-tenths flint; one entirely altered, has been bored by molluscs.

M. 44. One-third flint.

M. 50. A little flint.

M. 53. One-third flint.

M. 56. One-third flint.

M. 77. Three-quarters flint, in large size, one about $6^{\prime \prime} \times 6^{\prime \prime} \times 4^{\prime \prime}$.

M. 58. Two-thirds flint, in large size, one about $10^{\prime \prime} \times 6^{\prime \prime} \times 4^{\prime \prime}$.

M. 67. Over nine-tenths flint, large and entirely unrolled, roughly cylindrical, with short branches, one $18 \mathrm{~cm} . \times 13 \mathrm{~cm} . \times 15 \mathrm{crn}$, one $21 \mathrm{~cm} . \times 10 \mathrm{~cm}$.

M. 62. One-half flint.

M. 79. Three stones, of which one is flint.

M. 80. A little flint. 


\section{EOCENE.}

M. $77 \mathrm{~b} . \quad$ S. $11^{\circ}$ W. Edd., 38.8 miles.

A rough-textured cream-coloured limestone, rather soft, and closely resembling the 'calcaire grossier' of the Paris Basin.

Fine gravel or coarse sand is sparingly visible in the hand specimen. The microscope shows clear quartz grains, many of considerable size, and in the quartz fluid inclusions with bubbles. Fragments of
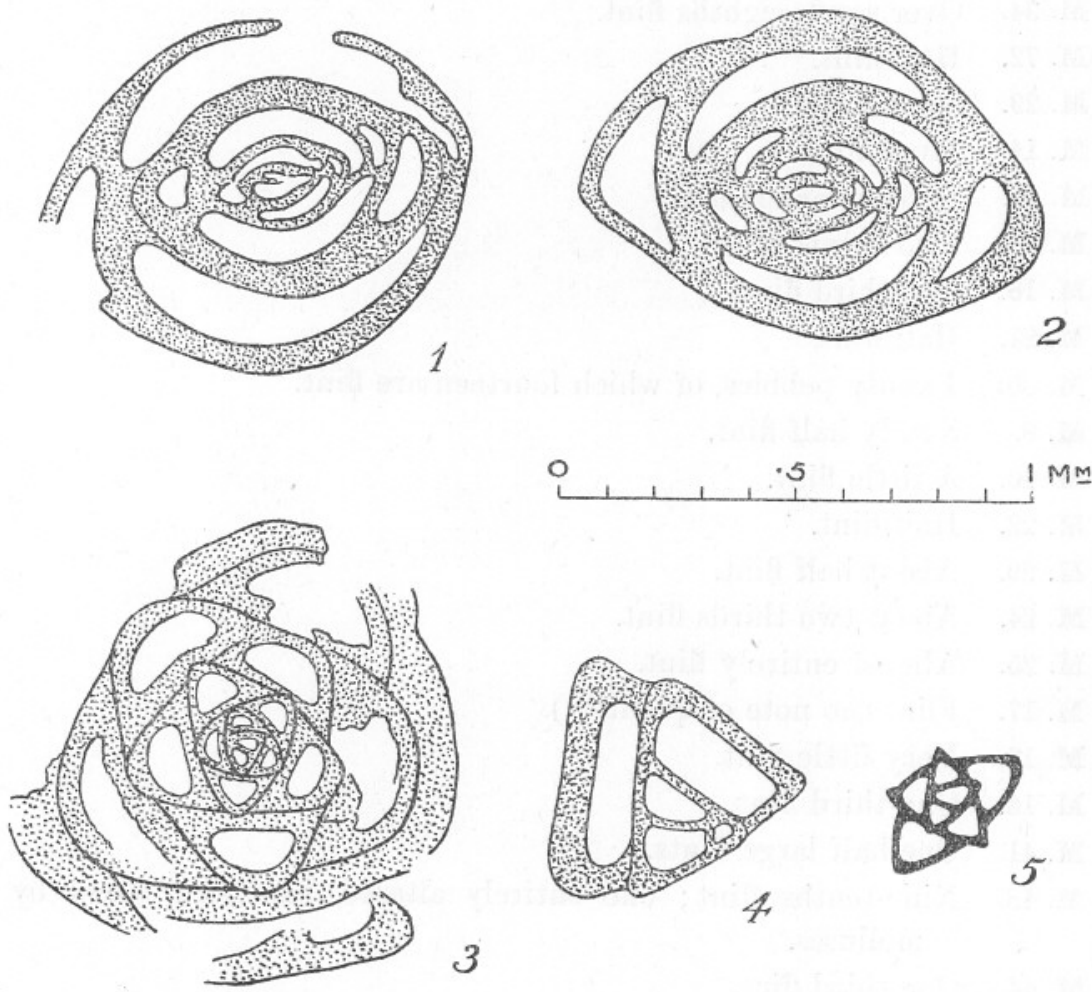

Fig. 2. Sections of foraminifera from $\mathbf{M} . \mathbf{7} \mathbf{z} \mathbf{b}$.

R.H.W.

1.2.3.5. Miliolina (Quinqueloculina) seminulum.

4. Miliolina (Triloculina) angularis.

hydroids and of corals are clearly distinguishable. But the feature of the rock is its foraminiferal character. Various forms of Miliolina preponderate; these certainly include Miliolina seminulum, Miliolina trigonula, Miliolina (Triloculina) angularis (d'Orbigny), and possibly other varieties.

Of other foraminifera Truncatulina refulgens (Mont.) is identifiable, and there appear to be two species of Discorbina; one species of 


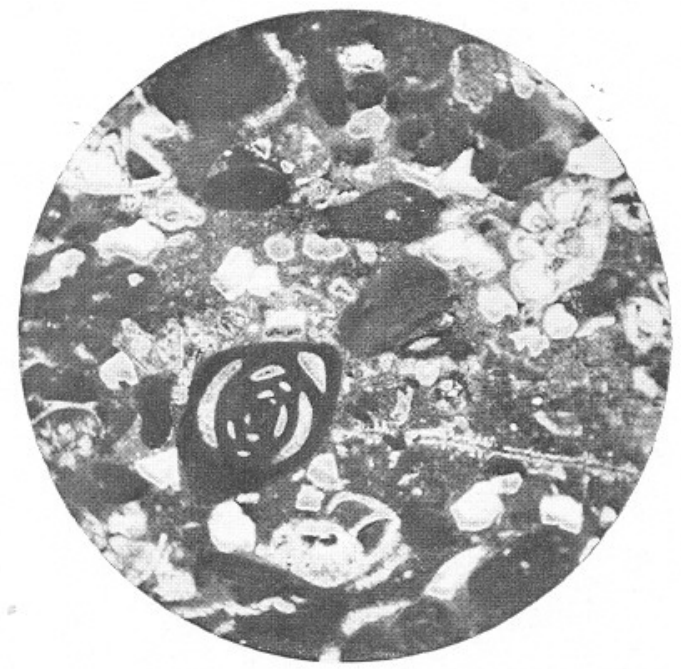

M. 77b. S. $11^{\circ}$ W. Fdd, 38 miles.

Eocene limestone.

Ordinary light. $\times 33 \frac{1}{2}$. 

Fig. 1.

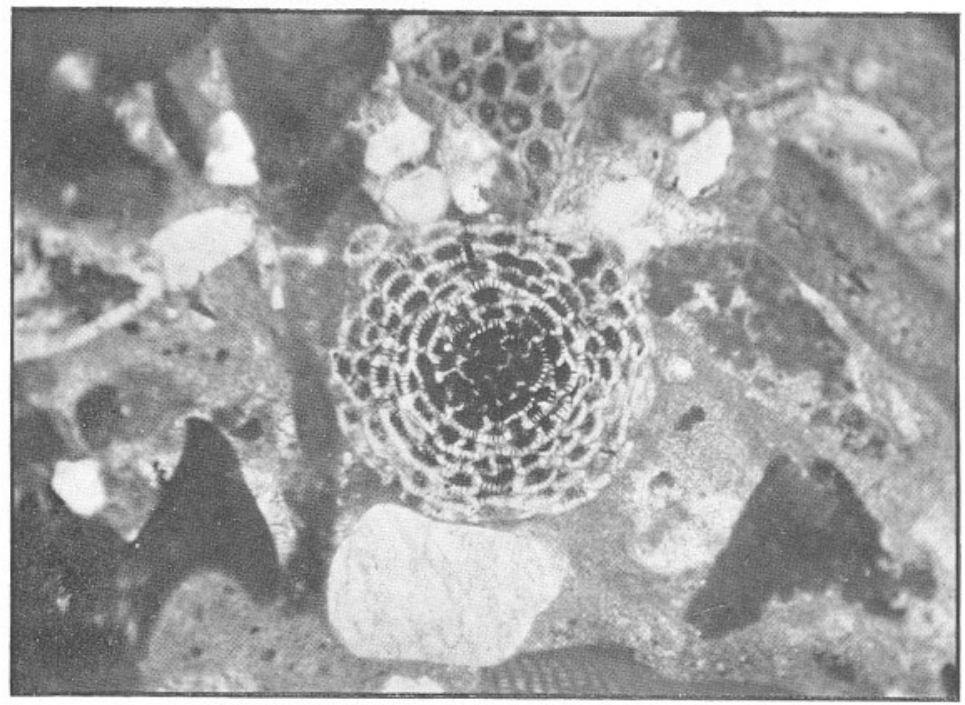

M. 77 b. S. $11^{\circ}$ W. Edd., $38 \cdot 8$ miles.

Section of Planorbulina (? larvata) in Eocene limestone. Ordinary light. $\times 44$.

FIG. 2.

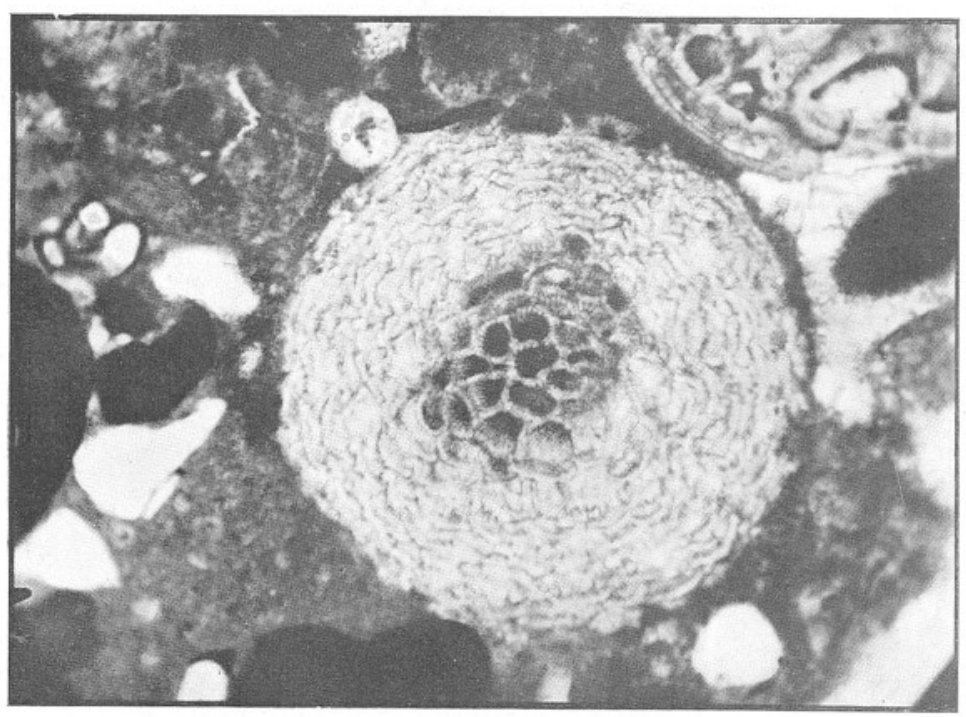

M. 77 b. $\quad$ s. $11^{\circ}$ W. Edd., 38.8 miles.

Section of Planorbulina (? larvata) in Eocene limestone. Ordinary light. $\times 44$. 
Verneuilina and one of Textularia, both the latter with arenaceous tests. Biloculina ringens is clearly present, and apparently a species of Polymorphina and one of Spiroloculina. There are several sections of a very beautiful foraminifera, all, however, in planes practically parallel to that of its spiral; still, cut at different parts of the thickness of the test, they give fairly clear information as to the form. It is certainly Planorbulina, and seems identical with Planorbulina larvata, Parker and Jones. This species is, however, only hitherto known as recent and of tropical habitat. The rock is too hard to admit the separation of the foraminifera as opaque objects, and sections must be relied upon wholly; so far three have been prepared, but many more will have to be cut before any certain identifications of the foraminifera can be made, except among the Miliolince and in a few chance instances where typical forms are fully displayed. Glauconite grains are common and of fair size, and the same mineral fills the chambers of many of the foraminifera. The foraminiferal shells have not been the subject of any mineral alteration. The groundmass of the rock has been a highly calcareous mud, with little aluminous matter. Comparatively shallow water conditions and a warm sea are indicated. (Plate XI and Plate XII, figs. 1 and 2.)

\section{ROCKS OF UNDETERMINED AGE.} SANDSTONE.

M. 14 d. S. $24^{\circ}$ W. Edd., 20 miles.

A buff-coloured sandstone with calcite cement, appears rather opentextured on outer face of pebble, but is quite compact within.

By far the greater number of grains are quartz, but a few felspars show in the slide. There are also some shell fragments and other organic remains. Many quartz grains show acicular crystals of apatite, some few have zircon enclosures. Some are nearly free from fluid inclusions, but most show rather many, with bubbles in the majority of instances. Many of the grains are iron-stained yellow along cracks, obviously before inclusion in this rock.

This rock has all the appearance of a ragstone, and may very possibly belong to the Neocomian formation.

\section{ARKOSE.}

M. $62 \mathrm{x}$. S. $42^{\circ}$ W. Edd., $46 \cdot 4$ miles.

The fracture shows a pale pink rock; externally the worn surface looks rather like sandstone in which the cementing material is less hard than the sand grains, the fractured surface seems more like a granular felsite; felspar of a light flesh colour is clearly visible. 
The section resembles a brecia, in which the individual grains are as well fitted to each other as the fragments in a tessellated pavement; thus there is a minimum of cementing matter. But, on the other hand, the normal constituents of granite, orthoclase, a little oligoclase, quartz, and some brown mica occur in much the proportions that would be found in a micro-granite, and very similarly distributed. Some of the felspar is micro-perthite. A great many felspars are cracked, some crushed, in each case the cementing material invades the crystal. Many of the quartz grains are similarly cracked, and the mica has been forced into curved forms to fit the surrounding grains, and in some cases has been structurally destroyed. The great majority of the grains of felspar and quartz show strain shadows in polarised light. The cementing material consists very largely of zoisite, with which is possibly a little felsitic matter. Small well-formed crystals of apatite and fluid inclusions with bubbles occur in the quartz. The felspar is fairly fresh and very little decomposed.

The rock has every appearance of a fine-grained granite, crushed, and then re-cemented by secondary minerals.

But for the appearance of the worn surface this would probably have passed in the hand specimen as a porphyritic felsite of the granitic class; it appears to agree precisely with the Mimophyre quartzeux of Brongniart, and the Granite recompose of French petrographers.

A precisely similar rock is found at-

IM. 13a. S. $26^{\circ}$ W. Edd., $17 \cdot 8$ miles.

M. 30 c. $\quad$ S. $21^{\circ}$ W. Edd., 21.5 miles.

M. 44 a. S. $17^{\circ}$ W. Edd., 29.8 miles. Distinctly angular block.

Its range is, therefore, about 29 miles at least.

\section{LIMESTONE.}

M. 80 e. S. $16 \frac{1}{2}^{\circ}$ W. Edd., 48.9 miles.

A large sub-angular stone, the surface distinctly polished. Very compact and hard. Brown with a vein of lighter buff or drab, dendritic markings on the lighter portion.

The section passes through both the mass of the specimen and a portion of the vein. Both consist of minutely granular crystalline material, largely calcite, but apparently dolomitic. The darker part gives indistinct evidence of organic remains, and shows clear rounded sand grains.

The rock is certainly puzzling, it may (doubtfully) have some affinity to the Cotham marble, but it would be a bold guess indeed to so identify it. 


\section{51a. S. $15^{\circ}$ W. Edd., 30.8 miles.}

While this paper is in the press the writer has examined a rock from M. 51, which he had previously overlooked. This is a compact, dark brown limestone, with large shell fragments, now in calcite. The stone is angular. It is but little softer than $\mathbf{M}$. 80e, and when sectioned shows dendritic markings similar to those in the lighter portion of that specimen. Undoubtedly liassic in type it in some sort forms a stepping stone from the more frequent forms to $\mathbf{M}$. 80e, and the latter may now with fair certainty be identified as liassic. In mapping purposes this has been assumed.

\section{GEOLOGY.}

In the preceding section the various rocks have been assigned to their respective formations and their peculiarities noted. In $\mathrm{Mr}$. Crawshay's paper their mode of occurrence, independently of their lithology, has been fully described. It remains to construct from the evidence thus called some coherent scheme of geology for this portion of the Channel.

With this end in view it is especially necessary to consider the probable date of these stony accumulations as such, and to find some reasonable explanation of their presence. Following which we must be assured that to some considerable extent the deposits are of local origin before we can proceed to any mapping of the various formations under the waters of the English Channel.

The one outstanding feature, as Mr. Crawshay has pointed out, is the general increase in average weight and size of the stones due south (magnetic), i.e. straight outwards into the Channel from the Eddystone. But although, as regards the dredged material, this fact is clear and important, against it or with it must be set the occurrence of large boulders on the Salcombe and Eddystone fishing grounds.

That the grade of the bottom deposit should grow coarser as the distance from land increases is against all probability and all experience, if the deposit is of recent formation under existing conditions. It should be expected that the detritus which enters the sea by the mouths of the rivers, derived from the denudation of the land, would so sort itself that the heavier and coarser particles deposit in the nearer and shallower waters, the lighter and finer particles coming to rest in the deeps; and, added to the river-borne detritus, the products of coast erosion and broken shells from the littoral zone should similarly distribute over the sea-bed with reference to the weight and size of their grains. No matter how small the rivers, how slight their supply of sands and clays, and without reference either to the rate of erosion and supply from the sea-cliffs, in time and in the absence of strong localised 
currents the bed of any sea will become covered with deposits, the average grade of which at any place will bear a relation to the depth and the distance from land. And the strength of the sea currents will in most instances accentuate this differentiation, being greatest in shallower water.

If, then, a contrary condition is found to exist, and the sands are replaced, even in parts, in the deeper water by coarse beds and blocks of stone, it becomes apparent that these latter belong in their origin to other conditions than those now prevalent. The present rivers, the cliffs which we see to-day have not supplied their material. Further, we may surmise that a sea which exhibits this anomalous feature, that the materials of its bed grow larger in individual constituent parts with distance from shore, cannot be, in its present form and depth, of very ancient origin. The time available has not sufficed to enable the shore-derived material to spread over the whole area.

AUsten has discussed these points very fully and with great clearness; in fairness to his work and in recognition of his precedence the matter may be stated in his own words ${ }^{1}$ :-

"The law of progressive change in the character of the sea-bed requires that the most remote deposits of the Channel should be the finest, and that no coarse materials should occur at any considerable distance from the coast; this law holds good for a given extent round all the shores of the Channel, but beyond the area of mud and ooze, fine and coarse sands, shingle and bare rock are again met with. . .." And referring to the coarse deposits on the Sole Banks and Jones Bank, "the whole of these groups [of coarse material] are separated from the zones of coarse materials depending on the coast-line by a broad intervening area of the finest quality of sea-bed. We are precluded from supposing that the lines of coarse materials can have travelled over the mud zones, as their upper surface is soft and incoherent, into which the sounding-lead sinks some distance before the mass is tenacious enough to stop it, and in which the dredge buries; if therefore marginal or sub-marginal zone materials are found in places beyond well-defined areas of the low moving power of water, they become a clear indication that since their accumulation a great change in the position of such place, as to depth of water and distance from coast-line, has taken place." . . . " It may be objected to this, that these distant sand, gravel, and shingle beds may belong to any age, and not in any way be connected with the present seas. In tracing the remains of marine animals seawards, we may observe a like gradual comminution with that noticed with respect to mineral 1 “Valley of the English Channel," Q.J.G.S., Vol. VI, 1850, p. 83 et seq. 
materials, long after the forms of the shells have ceased to be recognisable. The sea-bed, particularly on the French side of the Channel, is mainly composed of shell sand, or sand in which few particles of anything but such as show shell-structure occur. Areas of this character are laid down by the French surveyors, and occur in the interval between the Land's End of France, or Ushant, and the Little Sole Bank; yet on the sides of this bank, and more particularly on its western slopes, large, perfect, though decayed, shells again occur, and what is more remarkable, Patella vulgata, Turbo littoreus, etc. Taking the two phœnomena together, the occurrence of littoral shells and of marginal shingle, we may safely infer that we have at this place the indication of a coast-line of no very distant geological period, buried under a great depth of water, and removed to a great distance from the nearest present coast-line."

"... In the very coarse beds which form the floor or lowest levels of the deeps in the upper part of the Channel, from the meridian of Cape la Hague eastward, and which have a depth of forty and fifty fathoms, we also seem to have the highest marginal zone of some former period, over which the drifting beds of the actual period are spreading; and, on the other hand, such masses as Jones Bank are to be considered as protruding portions of an older sea-bed isolated amidst the ooze deposits of the present sea."

"... The character of the greater part of the Channel area, if laid bare, would be that of extensive plains of sand, surrounded by great zones of gravel and shingle ...; whilst along the opening of the Channel there is an obvious configuration of hill and valley, and an amount of inequality equal to that of the most mountainous part of Wales."

DELESSE attributes more to the action of currents in the deeper parts of the Channel than apparently would AUSTEN, but agrees that the coarser deposits are not of the present epoch, and argues that the settlement of the sands and silts of to-day has been prevented in certain areas by the strength of the currents, and hence these earlier deposits have been preserved from being covered. He writes ${ }^{1}$ :-

"La Manche étant balayée par des courants énergiques, on doit s'attendre à ce que son fond ne reçoive pas partout des dépôts, mais soit au contraire formé très souvent par des roches pierreuses antérieures à l'époque actuelle; c'est, en effet, ce qu'apprennent les sondages, et proportionnellement ces dernières roches y occupent même une étendue beaucoup plus grande que dans les autres mers. D'abord, elles présentent des surfaces très vastes dans tout l'Ouest de la Manche; elles bordent la Bretagne et la Cotentin auquel elles

1 Lithologie des Mers de France, p. 308 et seq. 
réunissent Jersey ainsi que les autres îles anglo-normandes; de plus elles réunissent la Bretagne au Cornouailles et le Cotentin au Sud de l'Angleterre. Elles sont découpées suivant des écharpes très irregulières; non-seulement elle longent les côtes, mais elles traversent complétement la Manche, se poursuivant jusque dans les parties les plus basses de son bassin et même jusque dans son thalweg."

"Ces roches sont assurément très variées; cependant entre la Bretagne, le Cotentin, le Cornouailles, et le Devonshire, elles appartiennent au granite et au terrain de transition. Les sondages font connaitre qu'elles sont en partie formées de pierres désagrégées; qu'en outre les roches pourries sont fréquentes autour de $49^{\circ} 5^{\prime}$ latitude et de $7^{\circ} 10^{\prime}$ longitude, dans le thalweg de la Manche."

Finally, when we deal with the boulders from the Salcombe-Eddystone grounds we have Mr. HunT's opinion. ${ }^{1}$

"My own contention being that they [the boulders] are to all intents and purposes in situ.

"The problem of origin is certainly a perplexing one. Those who maintain a distant derivation have to show where the blocks came from, and how they came.

"Those who contend for a local submarine origin have to explain how such solid blocks could have become detached from the parent beds.

"That trawls could detach the blocks from their beds is as possible as that 'Old Noll' fired them at the seagulls; but that trawlers could have dragged them about all over the Salcombe fishing grounds when detached is practically certain. Thus none of the detached blocks have any claim whatever to be considered in situ when caught, though they may fairly claim, I think, to represent rocks forming the bed of the Channel not far distant.

"However, it is clearly impossible to prove that some of them may not have been ice-borne. Let those who maintain that theory show cause for their belief."

We are somewhat more favourably situate now than when either of the above extracts left the hands of their authors. As regarding a definite line, from Plymouth Sound, past the Eddystone to a distance of nearly fifty miles from the latter, we have absolutely located and perfectly representative samples of the bottom deposit. From the 25 -fathom line to the 35 -fathom line these have been worked out in detail. Broadly speaking, the results are that we now know the Eddystone and, in part, the Hand Deeps to stand above the general

1 "'The Submarine Geology of the English Channel off the South Coast of Devon," Trans. Dev. Assoc., 1889, p. 484 et seq. 
level of a sea-bed which consists of fine gravel and fine shelly gravel in patches; while south and east for some distance from the Eddystone are fine sands. South of the Prawle promontory, off the coast-line from Bolt Head to Prawle, is shell gravel, from Prawle to Start, stony ground.

The fine sands are quite unlike the silty sand of Plymouth Sound, are coarser as a whole and cleaner. A chart which the writer prepared in 1898, from Dr. Allen's details, is here reproduced; the undetermined areas have not yet been fully worked, and perhaps are better left blank until full information is available. There is a little stony ground at East Rutts, a stony patch off Stoke Point, and stones have been dredged north of the Eddystone, and on the margin of the Hand Deeps. (Plate XIII.)

All the stations on this chart are those to which I have elsewhere prefixed the letter $\mathrm{A}$.

Station A. 100, south of the Eddystone, gave large stones as well as sand. Stations A. 78 and A. 31, although near to and surrounded in part by sand, were actually on rock, and A. 79 yielded Triassic sandstone. These three points are southward from the Eddystone, on the margin of the fine-sand area.

The first matter, the probable date of the stony deposits and their origin, may now be left for a time, to be resumed when the general geological mapping of the area has been attempted.

As to the second matter, the extent to which we may rely on the comparatively local origin of the various stones and pebbles, this, too, may be left in part to a later portion of the paper, but enough should be written here to justify the attempted location of the various formations in situ.

When a rock is obviously torn from its parent mass, as instanced by its form and freshly-broken surfaces, and when it comes from known rocky, as opposed to stony, ground, the inference as to its in situ origin is almost irresistible.

This is a matter of rare occurrence. HunT's H. 19 appears to have been a clear instance. The trawler Pelican got fast in what was supposed to be a wreck, and remained thus fast for some hours. When the trawl came away, a fragment of granite showing a clean fracture was found in it. This fragment, No. 19, differs from HunT's other specimens in that it evidently formed part of a thin slab of rock, and not of a massive block. The stone proved to be a granite of coarse grain, with white and black micas, and a little triclinic felspar in addition to the orthoclase. The locality 20 miles S.W. of Eddystone. From practically the same spot, M. 15, the recent dredgings 
raised a fine-grained granite also with both brown and silvery mica.

There is evidence that the rock bottom at A. 78, A. 79, is Triassic. While the gneiss from A. 86 (354/1), $\frac{1}{2}$ mile N.W. of Eddystone, was a large angular slab, with one face of apparently clean fracture.

Thus on this class of evidence granite, gneiss, and trias have alike been found in situ.

Another feature that argues strongly for a rock being near its first home is the angular or sub-angular form occasionally presented; especially is this form of evidence of value when the stone is such as will readily suffer from transport.

A. 100 (354/2), 2 miles S.W. of Eddystone, gave large stones, a thin slab of variegated Triassic sandstone, a rather thin slab of buff Triassic sandstone, and a thin piece of red marl, all angular and practically unworn. Such rocks as these could not travel without great wear.

M. 19. S. $28^{\circ}$ W. Edd., 23.3 miles, yielded large square blocks of Red Triassic Sandstone.

M. 14. S. $17^{\circ}$ W. Edd., $29 \cdot 8$ miles, yielded thin sharp slabs of Liassic limestone.

There are other similar instances. Evidence of this type again demonstrates practically in situ exposures of Trias, and in this case of Lias as well.

A third clear indication of localisation is when the adjacent seabottom yields rocks of the same class and type as shore exposures. The sea-bed off the Bolt and around the Eddystone affords instances.

To some extent coupled with this is a fourth strong class of evidence - the restriction of the occurrence of a given type rock to areas with definite boundaries. Thus the Bolt and Prawle schists vary in type as we proceed southward along the sea-bed. The Eddystone and HandDeeps gneisses are restricted to the immediate neighbourhood of the reef; in A. 102, S. Edd., $2 \frac{1}{2}$ miles, the gravel contained no Eddystone reef material, although in A. $87, \mathbf{N} . \mathbf{W}$. by N. Edd., 1 mile, $87 \%$ of it is derived from the reef. It will presently be seen how, on a much larger scale, the New Red Sandstone series is definitely bounded. Thus at M. 27 , S. $19^{\circ}$ W. Edd., 18.3 miles, there is a representative series of Triassic rocks; at M. 29 , S. $14^{\circ}$ W. Edd., 19.8 miles, these are entirely replaced by the marls of the passage-beds to the Rhaetic. The distance is under two miles.

Another, the fifth, possible proof that a rock is near its point of origin applies in but a few cases. An example will best explain it. On all the preceding arguments we may decide that the gneiss of the Hand Deeps is practically in situ. $354 / 3 \mathbf{b}$ is a red conglomerate of the 
New Red series; it contains derived fragments of the Hand Deeps gneiss and schist; it is found side by side with them, and hence if they are in situ so, too, in all probability, is it.

The sixth line of argument for the demonstration of the local origin of the rocks and pebbles is as strong as any. There are some rocks so friable that they might not travel half a mile without being destroyed. Many of the marls of $\mathbf{M}$. 29 above referred to are of this class, the 'paper shale' of M. 53a, S. $22^{\circ}$ W. Edd., 322 miles, is another rock which must be content to rest at home or be destroyed. From these which cannot be moved without destruction, through those which can only travel a little way without disintegration, on to others which may journey but must be considerably reduced in their progress and bear evidence of their wanderings, there is a complete succession. The extreme of the class may be taken to be flint, and if entirely unrolled flints are found, as at M. 67 , S. $19^{\circ}$ W. Edd., 40.5 miles, among other places, it may well be assumed that they are untravelled.

On some one or more of these six lines of argument every class of rock found in the dredgings may be shown to be practically in situ at one or more stations. Its associates are arguably almost equally near their points of origin, for it is impossible to attribute to any drift, arising from whatever cause, the selective and confounding ability to bring like to like, to transport from a distance and place among its kin any stone or stones. A little exchange of material between adjacent areas there must be, but we are not about to attempt any geological mapping within extreme narrow limits of error.

\section{THE CRYSTALLINE ROCKS.}

Granites, Diorites, Gneiss, Schist, etc.

Mr. A. R. Hunt quotes, in a paper above cited, a letter received by him from the late Mr. E. B. Tawney, as follows:-

"My views are rather Britannic; I look to Brittany for their origin [the origin of the Channel granites and gneisses, R.H.W.]. I consider Brittany reached to Plymouth Sound and then stopped short, but am inclined to give Start Point to it. If so, the granites are not all preDevonian, though pre-Carboniferous."

To much the same conclusion the writer has arrived, as at least a working hypothesis, with the correction that some at least of the Brittany granites are now commonly accepted as of Carboniferous age.

To one who has worked in a granite area such as Dartmoor there is nothing unexpected, nothing disappointing in finding, as in the present instance, such considerable variety among the plutonic rocks, 
a variety that by no means in all cases involves difference of origin.

For the moment all granites and associated rocks which may have had a Dartmoor origin are excluded from consideration; these are extremely few in number. The first part of this paper must be left to speak as to the variety of the plutonic rocks met in these dredgings. But here such slight evidence of relative age as can be adduced may well be considered. Gneiss is known to occur at the Eddystone in situ; it occurs also at the Hand Deeps and the East Rutts, and notwithstanding the doubt thrown upon the fact, I am inclined to consider that the 'Shovel Reef specimen' was, indeed, obtained near Plymouth Breakwater. This has been rendered the more probable by discoveries made since the time when $\mathrm{Mr}$. A. R. Hunt, on evidence that warranted him in all fairness, challenged the fact.

We now know, as we did not then, that gneiss occurs at the East Rutts, and chlorite schist off Stoke Point, in each case without any trace of their presence being visible on shore.

Gneiss also occurs at M. 36, M. 9, M. 16, and M. 25 stations, which all lie in a narrow north and south strip, extending from 17.5 miles S. $37^{\circ} \mathrm{W}$. from the Eddystone to 23 miles S. $24^{\circ} \mathrm{W}$. from the Eddystone, a strip not quite three miles broad. M. 11x and M. $20 \mathrm{~g}$ might also be classed as gneiss, and would somewhat broaden the patch referred to. In any event there is a certain localisation about these associated rocks. The writer has always hitherto leant to the hypothesis that the Eddystone gneiss was of Archæan age. From the features of similarity the gneiss from this area would presumedly be of the same formation. And there is an interesting piece of evidence which at least tends to indicate age. A number of grit stones have been dredged from various parts of the area examined (see p. 142). Among these is M. 9d, and that rock contains as derived fragments particles of just such gneisses as occur in the neighbourhood.

It is impossible to correctly date the grits, which may be either Carboniferous or earlier, perhaps more probably the latter.

Turning next to the schists. One of the most interesting finds was off Stoke Point, where chlorite schist is not uncommon (see p. 139). This brings the Bolt series many miles west. For the rest, the petrological notes give all the useful information.

As bearing on the age of some of the plutonic rocks we have to observe that there is an area over which slates are common which show evidence of contact metamorphism. The northernmost point of this area is M. 11 , S. $26^{\circ}$ W. Edd., 17.8 miles, the southernmost is M. 24 , S. $24^{\circ}$ W. Edd., 22.5 miles, about five miles long; the patch is from one to 


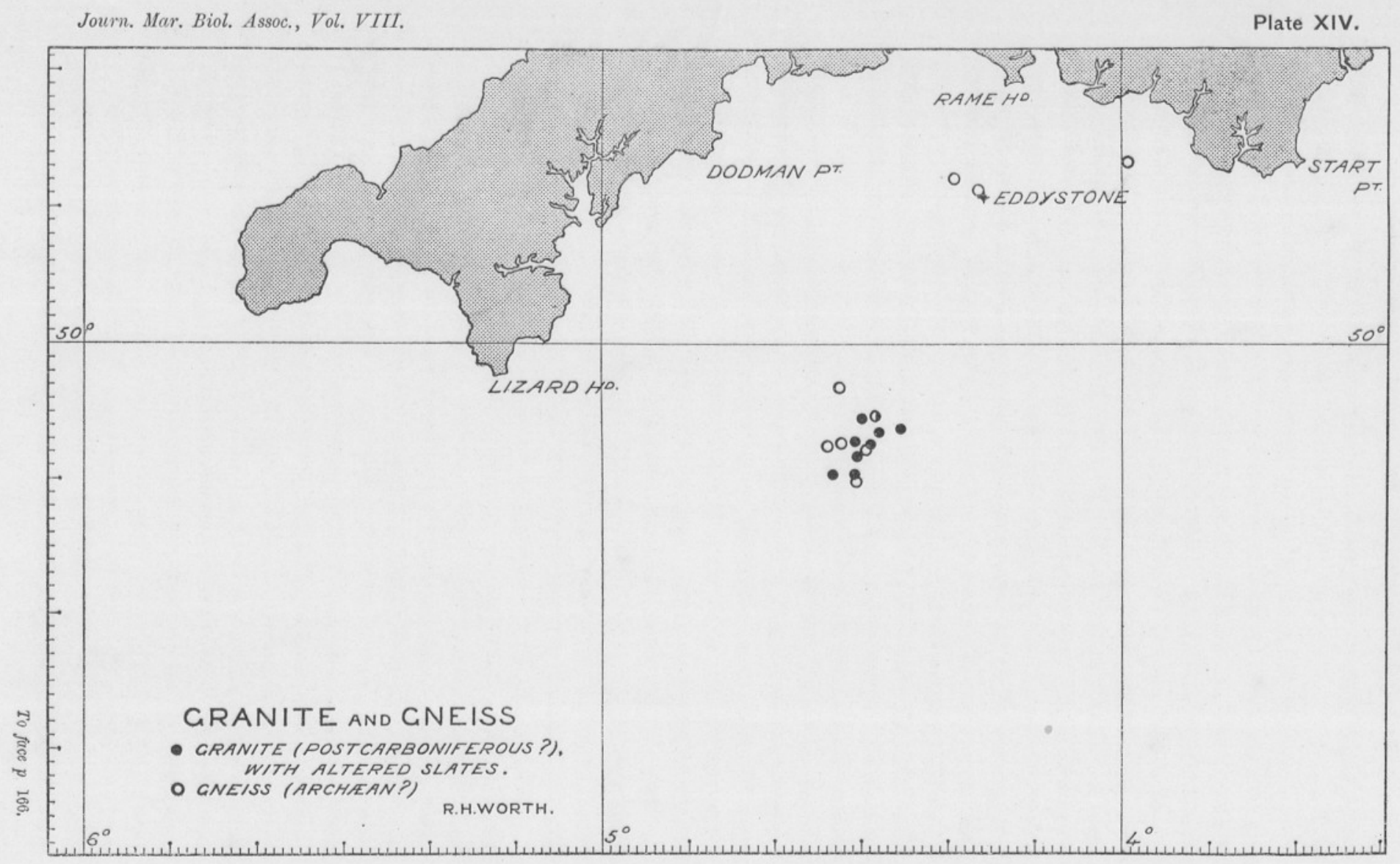


three miles in breadth (see p. 144); it is quite possible that similar rock in small quantity may occur outside this area and have been overlooked. M. 14j has been taken as the type. Possibly these slates are carboniferous; they more resemble the carboniferous series lithologically than the Devonian. It is to be noted that side by side with these slates occurs a red felsite, and red granites occur also. This distinctly looks like an area where the contact plane of the granite and the sedimentary rock is near to or reaches the surface. Felsites and red-coloured granites would be expected near the junction. If these slates are carboniferous, then the granite is post-carboniferous; if Devonian, the granite is post-Devonian, in any event not preDevonian. Some interesting features attend this area of altered rock. It is true that Hunt's H. 19 granite in situ occurs 20 miles S.W. of Eddystone. Here, too, have been found the only specimens of schorlaceous granite or aplite M. 11c, M. 27x ; hence come the other true aplites M. 24g, M. 14e, M. 34e ; and hence we derive the micro-pegmatite, M. 11a., all granitic, and not dioritic rocks. The only schorl rocks, except M. 14 and M. 72, come, however, from M. 31 and M. 36, one to two miles north of this area, and possibly in the absence of $\mathbf{M}$. 11c., M. $27 \mathrm{x}$ would be regarded as strays. Such was the writer's first thought; but considering the nature of the adjacent rocks, he now inclines to believe that both schorl rock and schorlaceous granite truly belong to the area. The presence, in addition to the above-named, of diorite, quartz diorite, and some intermediate igneous rocks is not overlooked.

The areas of gneiss and altered slate lie side by side, but neither can claim exclusive occupation of its portion of the bed of the Channel. (Plate XIV.)

Since very little good can result, with the present materials, from any further attempt to deal with the plutonic and metamorphic rocks, we next turn to the New Red Sandstone, which overlaps and partially overlies the district just considered.

\section{NEW RED SANDSTONE.}

The westernmost shore exposures of New Red Sandstone are at Thurlestone in Bigbury Bay, and in Cawsand Bay on the Mount Edgcumbe shore. There is also on the beach at Drake's Island in Plymouth Sound an untravelled block of breccia of Triassic aspect, weighing about four or five tons.

The mica-andesite (felsite of the Geological Survey) at Withnoe in Whitsand Bay is an intrusive rock, evidently connected with the red trap in Cawsand Bay, and undoubtedly of New Red age. 354/4b $6 \frac{1}{2}$ miles W. from Rame Head lies on another exposure of this same igneous series. 
DE LA BECHE, whose work stands as a model of careful discovery and accurate inference, with reference to the red trap of Cawsand writes: "Though unable to adduce direct proof, we are inclined to refer this porphyry, from its general character, to the date of the lower part of the red sandstone series, and to infer that it may be connected with a portion of that series beneath the sea in the direction of Bigbury Bay, on the coast of which, near Thurlestone, we find the patch above noticed."1

In 1867 Pengelly, and in 1886 Worth, supplied proof and confirmation as to the age of the 'porphyry.' And in 1898 the writer, as the result of Dr. Allen's dredgings, was able to assert that there was strong evidence that from the Hand Deeps to Bigbury Bay the New Red rocks were continuous. It may now be added that conglomerates dredged from off the Mewstone Ledge are distinctly of the New Red type. In the gravels and sands between the Eddystone and the Bolt New Red materials everywhere constitute a considerable percentage of the rock fragments.

In the vicinity of the Eddystone and the Hand Deeps New Red rocks are found in situ (wherever rock is exposed), through which protrude the reefs. The conglomerate at the Hand Deeps contains fragments of the local schists and gneisses.

The lithology of these rocks having been fully treated of in the first part of the paper, it is not proposed to make any repetition here, but pages 144 to 148 inclusive may be referred to. Although the variety of the rocks is considerable, all, or almost all, appear to be Triassic rather than Permian in character.

Only one of HuNT's specimens has any bearing on this formation, and that is H. 10, S. Edd., 20 miles - "Triassic Sandstone."

WoRTH's discoveries further westward, meeting and overlapping the Association's latest dredgings, are of especial importance; these carry the Trias to a point W. 5, S.W. by S. (mag) Dodman, 25 miles, roughly 36 miles from the Eddystone. ${ }^{2}$ He doubted the eastward extension of the outlier, on evidence which has interest as confirming the Association's results. In fact the Trias does so extend, but his two easternmost points lay one on either side of the broad belt which it forms. His W. 12, S. by E. Dodman, 27 miles, lies about 3 miles north-east from M. 29, and at the latter point we now know that the Trias has given place to higher strata. W. 12 yielded no Triassic rocks.

His W. 6, S. by W. Dodman, 20 miles, in addition to a salmon-tinted

1 Report on the Geology of Cornwall, Devon, and West Somerset, p. 212, 1839.

2 "On a Submarine Triassic Outlier in the English Channel," Q.J.G.S., Vol, XLII, 1886, p. $313-15$. 
Journo. Mar. Biol. Assoc., Vol. VIII.

Plate -XV.

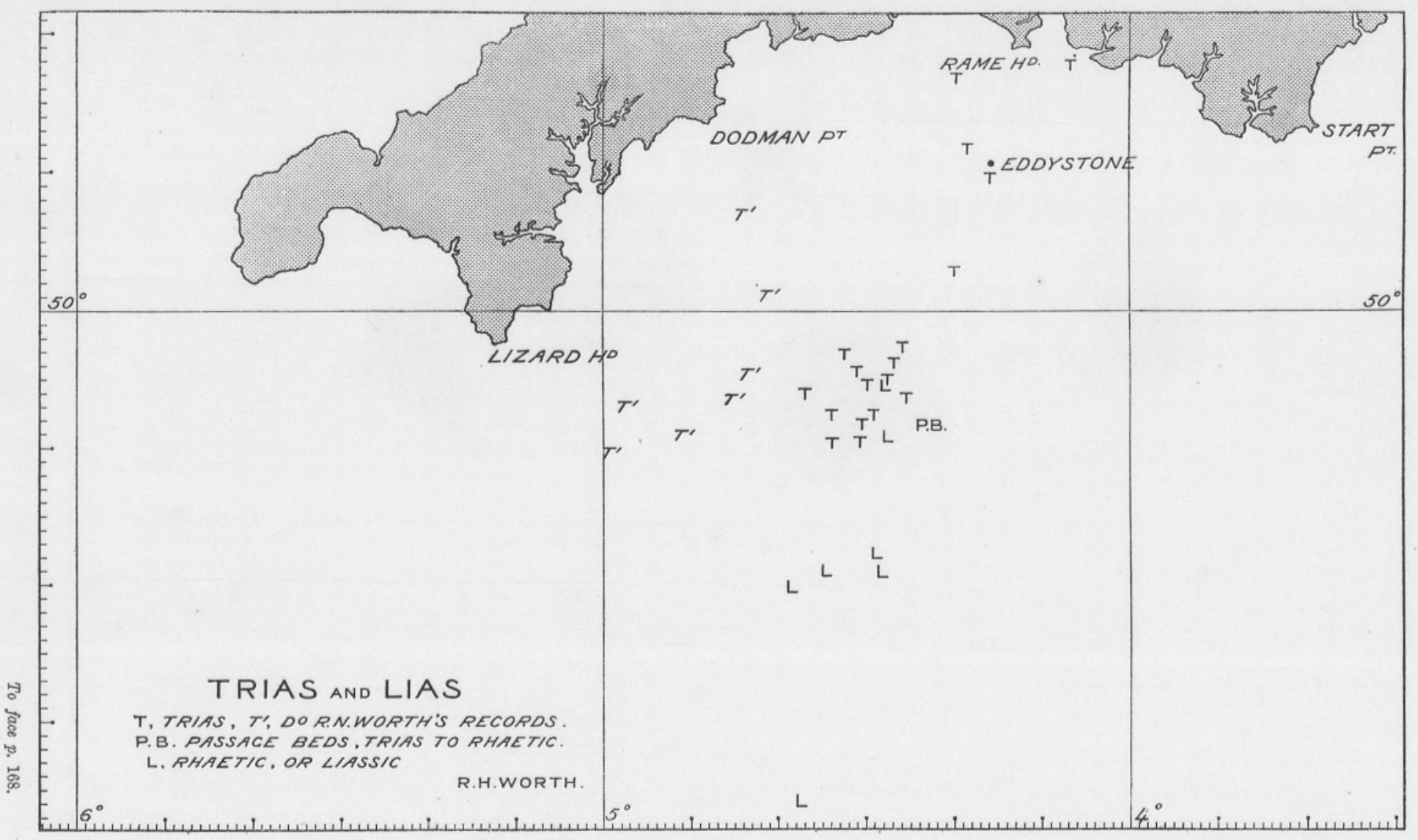




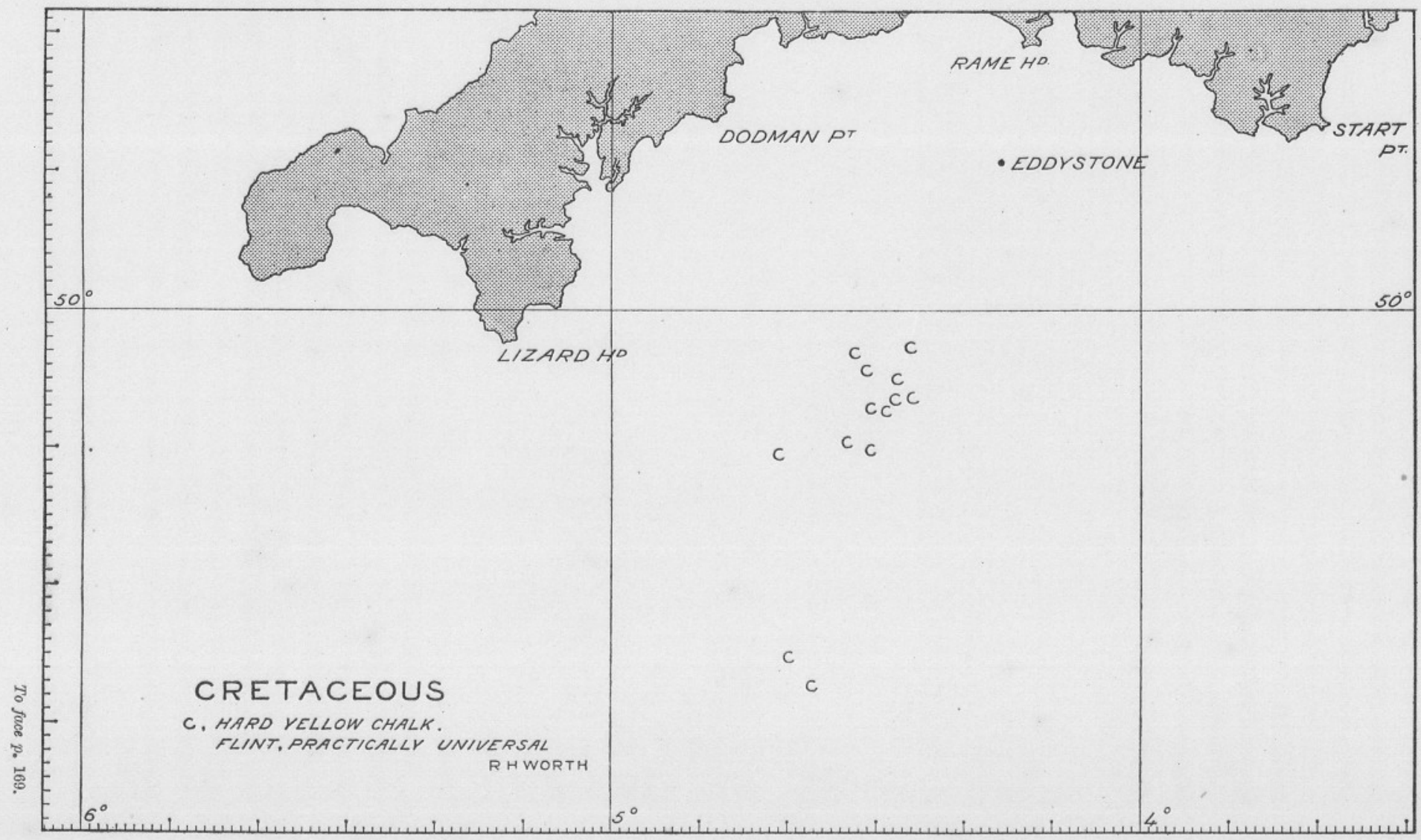


calcareous san dstone (Triassic), yielded pebbles of granitic, granitoid, and quartzite rocks, with flints, thus confirming M. 40, five miles westward.

On the chart here inserted the letter $\mathrm{T}$ indicates those dredgings made by the Association in which New Red rocks have been found; while Worth's records are marked T'. (Plate XV.)

The point at which the passage-beds above the Trias were found is marked P.B., and L indicates limestones and marls of Liassic type.

\section{CRETACEOUS.}

Inasmuch as flints are recorded from practically every dredging, it is useless to place the localities on a special chart.

A chart has, however, been prepared showing the distribution of the hard yellow chalk. The northernmost location would appear to be Hunt's H. 13, S.W. Edd.,15 miles; his record of "a small piece of buffcoloured limestone, riddled through and through by molluses and other marine borers," probably refers to a piece of this chalk. From this point to M. 41, a distance of, say, 11 miles, records are frequent in the Association's dredgings. There is then a gap for about 14 miles, and following this two localities occur, M. 58 and M. 67. (Plate XVI.)

The affinities of this yellow chalk appear to be with the 'Melbourn Rock,' described by Mr. A. J. Jukes-Browne, and later by the same author in collaboration with $\mathrm{Mr}$. W. Hill. ${ }^{1}$

Whether lithological similarity in this case implies identity of age may be doubtful. But the writer is indebted to $\mathrm{Mr}$. Jukes-Browne for the loan of some slides from his collection, and finds much in common between these and his own slides prepared from the dredged material. Unfortunately the latter contains no recognisable remains of any zonal fossils. If of the same age as the Melbourn Rock, the specimens indicate a formation lying at the base of the Middle Chalk.

\section{EOCENE.}

The one block of Eocene limestone is of great interest; it is large, over one foot in length, flat-bedded, and angular. From its nature it cannot have travelled far and preserved its present form; indeed, it must practically have been taken in situ.

The possibility of Eocene strata occupying some part of the western bed of the English Channel had been recognised before this specimen was taken, and the grounds for that recognition have been so well summarised by Mr. Jukes-Browne, that no apology is needed for inserting here an extract from his work, The Building of the British Isles (1892):-

"From the superposition of marine limestones upon the lignitic

1 “The Melbourn Rock, ete.," Q.J.G.S., Vol. XLII, 1886, p. 216 et seq. 
series of the Paris Basin, and the sudden appearance in them and in their English equivalents of tropical forms of mollusca, it was formerly supposed that a subsidence took place which submerged part of the intervening land and allowed the waters of the great Eocene Mediterranean to occupy a portion of the low-lying tract on the northern side of the barrier. But the discovery by M. Vasseur of deposits with fossils of the Calcaire Grossier age near the mouth of the Loire, and the identity of their fauna with that of similar deposits in the little basin of Carentan in Normandy, makes it much more probable that the

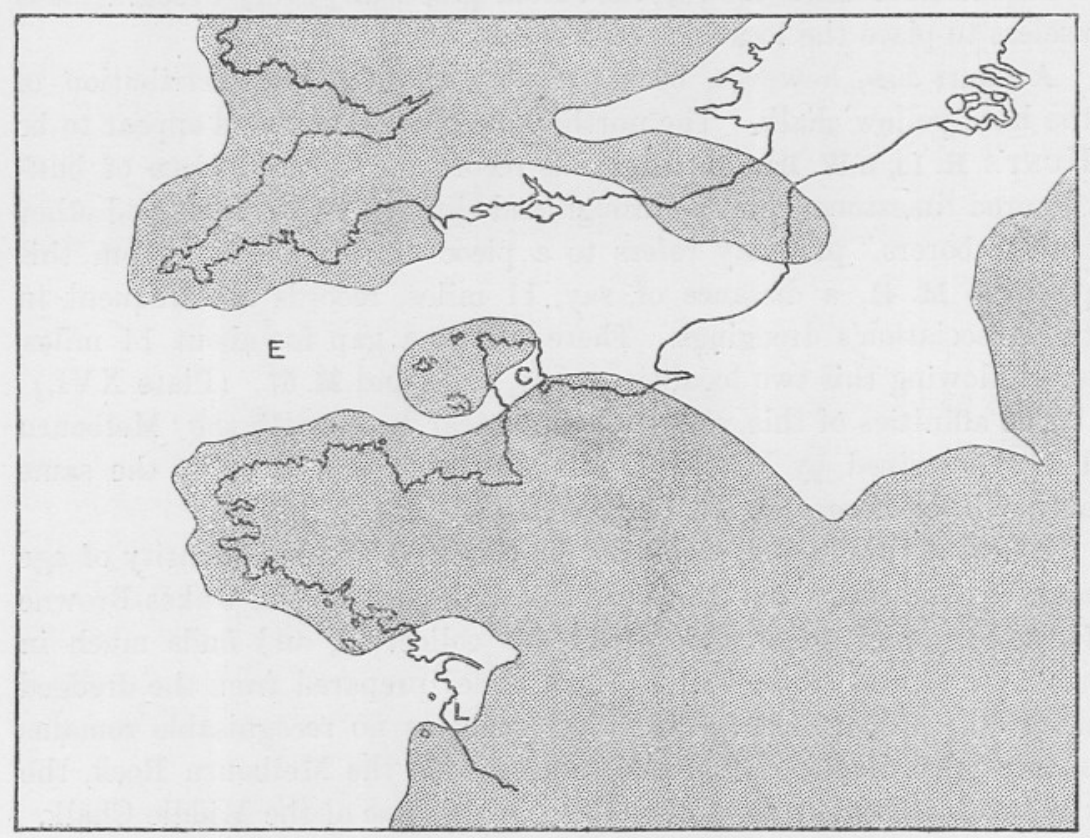

Frg. 3. The English Channel in the Middle Eocene Period. Land areas shaded. (After Jukes-Browne.)

incursion of warmer water came from the Atlantic. Professor Hébert remarks that the height of the ground between Carentan and Rennes makes it impossible to suppose that these two basins were directly united. Brittany must have formed a promontory between the inlet of the Loire and a channel which ran through what is now the opening of the English Channel. M. Dollfus is of the same opinion, and has recently proved by his researches along the south side of the Paris Basin that there was a continuous shore-line along that district throughout the whole of the Eocene period.

"It is fairly certain, therefore, that the opening was westward, and was nothing less than an incursion of the Atlantic into the North 
European region. We may suppose that the Atlantic waves had long been thundering against the western land which united France to Ireland, and that at last only a narrow tract of rocky land between Cornwall and Brittany remained to separate the western ocean from the lowland of the Anglo-Parisian area. The final breaching of this was accomplished during the subsidence to which the Calcaire Grossier testifies; the waters of the Atlantic soon widened the straits, and established a sub-tropical fauna and flora on the southern shores of Britain."

Mr. Jukes-Browne gives a map showing the geography of the Anglo-Gallic area as so interpreted; this with some addition and curtailment is here reproduced (Text, fig. 3). The Eocene of Carentan has been marked ' $C$ ', the similar strata near the mouth of the Loire have been marked ' $L$,' and the position of the dredging $\mathbf{M}$. 77, from which came the Eocene limestone, is indicated by the letter 'E.' The confirmation afforded by this discovery to the views of French geologists, in a problem the key to which lies in their country, is a pleasant matter to record.

\section{GENERAL CONCLUSIONS.}

The affinities of the crystalline rocks in the area examined are strongly toward Brittany, and but slightly toward the mainland of Devon and Cornwall.

There is evidence, amounting at the least to a strong suspicion, that the granite which occurs at and around a point 20 miles south $26^{\circ}$ west from the Eddystone is post-carboniferous; and this granite exhibits a tendency toward the Dartmoor type.

The Triassic outlier off the Lizard and Dodman discovered by the late R. N. Worth has proved to be connected eastward with an even larger area of New Red Sandstone rocks, which may very probably be continuous with the nearest shore exposures.

A clear indication of the eastern boundary of the Trias has been found at a point about 20 miles south $17^{\circ}$ west of the Eddystone. There seems fair reason to suppose that the western boundary of the Jurassic formations may for a short distance approximate to a line drawn south-west from this point. It may, however, be noted that Lias limestone was found in a detrital deposit at Cattedown (Plymouth) by the late R. N. Worth.

The Cretaceous rocks dredged from the Channel are now for the first time recognised to include chalk as well as flint. There is some possibility that the rock found is from the base of the Middle Chalk.

Flints, in addition to occurring on modern beaches, are found also in the raised beaches of Devon and Cornwall; were very numerous, 
associated with Dartmoor rocks, in the detrital deposits lying on the limestone at Cattedown, and examined by R. N. Worth; have been found by the writer, again associated with Dartmoor rocks, on the floor of clay-filled fissures in the Plymouth Limestone 20 feet below low water, and have been found by him on the rock beds of the Plymouth estuaries, buried beneath the silt.

As a result of the dredgings a considerable westerly extension of the boundary lines of the Trias, the Lias, and the Cretaceous must be made on our maps, beyond the present usually accepted speculative bounds. And the theory of an Eocene drift, sometimes put forward to account for the flints, must be abandoned.

It appears that from distant geologic time a depression has existed, having the same trend as the western part of the English Channel, and occupying a part at least of the same area. The New Red Sandstone first distinctly shows the previous existence of this depression. From Torbay to Plymouth the northern verge of the New Red deposits touches the present shore-line here and there; always the derived fragments in the conglomerates and sandstones are largely from local rocks. From Plymouth to nine miles south-east of the Lizard it runs parallel to the coast without absolutely touching it, and how far further west it extends we do not at present know. An arm of the great inland sea of this period, probably of its later or Triassic years, had its northern shore much where the waters of the Channel now meet the cliffs of Devon and Cornwall. How wide the Trias lake was along this western extension cannot at present be known; its deposits are lost under those of the succeeding Liassic sea, perhaps to reappear nearer France, perhaps not.

During the later Jurassic period this depression would appear to have slowly risen free from the waters, and in part, if not in whole, to have become a subaerial valley.

The Cretaceous era witnessed its entire submergence, although the highest points of Devon, where Dartmoor and Exmoor now stand, may have appeared as islands above the surrounding waters.

This submergence was gradual. A problematic coast-line of the time of the Lower Chalk has been laid down by Mr. Jukes-Browne. ${ }^{1}$ By that author's consent the map accompanying his paper in the Transactions of the Devonshire Association is here reproduced (Text, fig. 4).

It may be that the westerly extension of the Cenomanian sea has not been sufficiently prolonged; be that as it may, the sea of the Upper Chalk sent an arm westward to the Lizard parallel or probably beyond.

1 "Devonshire in the Time of the Lower Chalk," Trans. Dev. Assoc., Vol. XXXV, 1903 , p. 787 et seq. 


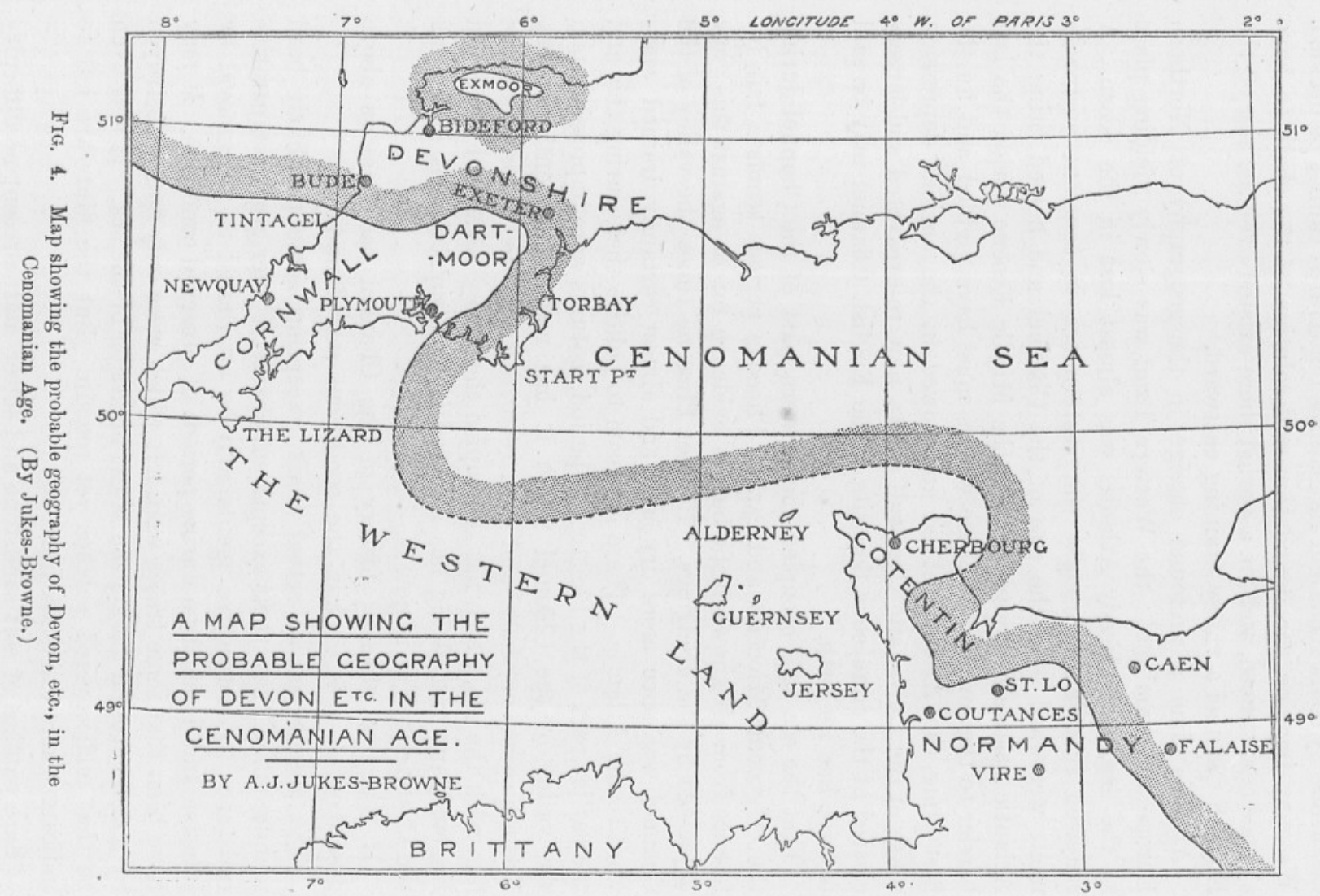


The next movement of the earth's surface involved an emergence of the land, and the depression which we are considering came into subaerial conditions once more; how far it had been filled in the meantime by chalk rocks and its features obliterated cannot be decided. We may imagine the denudation and solution of the chalk to have at once commenced, and for a period there existed over the site of the English Channel a valley draining eastward.

At this time a profound change in the geography of Northern Europe was imminent; the Western Land was slowly yielding place to the sea, and already Atlantis was almost lost in the ocean. A renewed subsidence brought the eastern sea in constant encroachment westward over the site of the Channel and helped bring the Atlantic eastward toward it. In the Middle Eocene period the last barrier to the junction of these waters must have yielded, and for the first time the Atlantic ebbed and flowed in the ancient depression south of the Devon and Cornwall coasts, now re-excavated and largely cleared of the cretaceous deposits. The English Channel may be said to have had its birth.

That the sea still occupied the western part of the Channel during the Oligocene, Miocene, and earlier Pliocene periods seems a fair inference from all known facts, but no evidence for or against this view is yielded by the dredgings. In later Pliocene times the valley of the Channel was once more dry land, and almost certainly drained westward to the Atlantic. There is reason to believe that, during this and the earlier part of the Pleistocene period, features were impressed upon the valley of the Channel which it has never since entirely lost. Despite occasional halts and even retrogressions, the victory has since lain with the sea, which has reoccupied the valley between France and England, and in so doing has modified its contour, bringing into being the Channel bed as it now is.

If the true physical history of the Channel has been as above described, does it explain the conditions now found?

The absence of all actual chalk, excepting some peculiarly hard nodules which from their exceptional character offer great comparative resistance to destructive agents, may be attributed to its removal by solution and denudation during periods of subaerial condition. It may have been that some traces were left which were only finally destroyed by marine erosion during the latest incursion of the sea. It may even be that undiscovered patches yet remain. But the flints are left to indicate where the chalk has been.

Bare patches of soft sandstone and softer marl present no difficulty of explanation. Assuming the last subsidence to have been even 
moderately rapid, the shore-line would never have presented any considerable height of cliff. Fringing the cliff in all bays and many creeks would be beaches of sand and shingle derived chiefly from the local rocks. Beyond the beach, where soft strata existed would be tidal plains of marine erosion, such level surfaces as now exist between tide-marks in Torbay. The constant advarce of the sea, the constant depression of the land, would ever carry forward the line of shore, the sea-cliff for the time being existent, and the beach would follow; its material would always be largely derived from the actual cliff, but in part consist of older material driven forward by the waves. The rocky plain would sink beneath the sea, and be left as a rather uniform surface of slight gradient seaward. Little or no beach would be left behind, and the older constituents of the beaches, those derived from the outer previous shore-lines, would never long persist, the constant wear reducing and destroying them.

Boulders from harder rocks would not be driven on in the same manner as pebbles and shingle, but would remain near their points of origin. Until, however, some considerable depth of water flowed over them, such boulders would still be liable to wear from exceptional wave action; and, further, we may consider that, especially with the granitoid rocks, submarine weathering must produce, but in a greatly less degree, the familiar effects of subaerial exposure. The chief and important difference would arise from the more uniform temperature of the sea.

There is reason to believe that the first inlet of the sea was somewhat long and narrow, a comparatively sheltered area, where wave action would be slight. That large and relatively unworn stones might be left here would be no occasion for surprise. And as the land sank and the Channel widened, this first-formed portion of its bed would still receive some shelter, until it was covered with water too deep to permit destructive wave-action. Extending the argument, there seems here a reasonable explanation of the general increase in the size of the dredged stony material outward into the Channel. Other causes may have co-operated. That wave action beyond the forty-fathom line has little or no destructive effect upon the pebbles at present, may be judged by the existence of pieces of yellow chalk and of Lias limestone bored and riddled through and through and yet in pebble form.

But in a narrow sea, while the wave action would be slight the tidal currents would be swift, and sand would not readily deposit; hence the fact that these stones were not buried beneath finer deposits derived from the shores. 
Even now, could the fine sands which float about in the Channel find a resting-place in its main water-way, a very short period would suffice to bury the stones and boulders. The surface tow-nets used on the cruises undertaken for the purposes of the International Sea Fisheries Investigations constantly catch considerable quantities of fine sand. But sand whicb by wave disturbance can be maintained at the surface over a depth of forty or fifty fathoms requires but a slight current to prevent it coming to rest on the bottom. It is not necessarily that the currents scour the inorganic sand from the seabed, but that they prevent its settlement there.

As regarding organic carbonate of lime, shell, and other material, which is forming even now in the deeper parts of the Channel, the currents must be credited with removing some of this mechanically, some by solution, as the particles become finer by disintegration, and the redeposit of such material must take place in quieter waters. Otherwise from the accumulation of this débris alone the stones would long since have been entirely covered.

Defective argument may be based on accurate observation, and if the hypotheses above put forward are found incapable of bearing the test of closer reasoning or of fresh discovery, the apology for their being must stand-that they are based in fact, and in fact the statement of which has been in no way influenced by them.

On two points further work is in hand: the examination of the flints for fossils, and the closer inspection of the baked shales from the neighbourhood of the presumedly Post-Carboniferous Granite.

\section{AN ADDITIONAL NOTE.-THE SANDS AND GRAVELS.}

Fine materials, sands and gravel, from eighteen dredgings have been examined, but not in such detail as might be desirable.

As a whole the mineralogical results confirm the conclusions derived from the stone samples; so closely are these in agreement that a very few points need be noted.

M. 29. S. $14^{\circ}$ W. Edd., 19.8 miles, gives exactly the same results in the fine material as in the pebbles, small fragments of the passage-bed marls being fairly frequent, and no Triassic rocks present.

M. 71. S. 23 W. Edd., $19 \cdot 0$ miles, yields Triassic material, which M. 72, a coarse dredging from the same spot, did not; this is within the New Red Sandstone area.

M. 75 . S. $20^{\circ}$ W. Edd., $38 \cdot 1$ miles, yields a little Trias.

M. $65 . \quad$ S. $22^{\circ}$ W. Edd., $42 \cdot 2$ miles, possibly contains a little Triassic material. 
The southernmost find of New Red Sandstone rocks among the pebbles having been M. 18, S. $29^{\circ}$ W. Edd., 23.4 miles, this trace of the same in the sands shows in all probability an outward and downward movement of small quantities of detritus, extending nearly twenty miles, certainly fifteen miles. This is the only evidence of any but very restricted movement among the mineral constituents of the sands, and it must be remembered that Triassic sandstones and marls are present in great quantity on their own area, and the amount of detritus would be proportionately large, some might well have trespassed on to other ground.

In all but this matter the inorganic sands agree so precisely with the closely adjacent coarse deposits, even in minute detail, and their constituents are so exactly parallel, that great strength is given to the previously urged view as to the value of the dredgings for approximate geological mapping.

In the gravels of some dredgings sharp chips of brown flints are rather common. Such angular flint flakes were taken at M. 37, S. $41^{\circ}$ W. Edd., $17 \cdot 1$ miles, M. 71 , M. 40, M. 73, M. 56, M. 75, M 76, M. 65 , and M. 61 , S. $25^{\circ}$ W. Edd., $46 \cdot 4$ miles, extending thus over a long range. For the more part the surfaces of the chips are practically undecomposed, and all are of brown flint. (It is black flint which chiefly shows the extreme alteration referred to in an earlier part of this paper.) These chips do not, however, look quite recent. They are such as would be formed by the mutual impact of subangular flints, possibly but rarely of broken flint pebbles. They could never last long on a beach or in any depth of water to which considerable wave action extended, although such wave action might constantly create a fresh supply. With a stationary shore-line a few such chips might be found a little below low-water mark, but only rarely. On the other hand, with an advancing shore-line and constantly deepening water it is quite easy to imagine that, formed on beaches or in shallow water, they might be placed in deeper water conditions soon enough to preserve many of them from destruction. Taking the deposit at Hallsands as an instance of a flint beach, long stationary, I may say that I have never dredged off that shore any such flint chips, although it must be imagined that some are at times formed. But probably one reason for their absence at Hallsands is the extent to which the shingle has been rounded, and a broken pebble is most rarely found; while with the sea advancing over a land surface covered with unrolled flints the process of rounding these into pebbles or commencing such rounding would give rise to very numerous chips. The fragments are therefore the supplement of the subangular blocks of flint still associated with them, 
and they persist-firstly, because the original supply was great; secondly, because for some time after their formation the sea was constantly deepening over them; and lastly, those only remain which have formed from material capable of resisting decomposition.

\section{APPENDIX I.}

M. DeLessse on the English Channel. Translated extract. ${ }^{1}$

" $L a$ Manche, which washes the whole north-west of France, is a shallow sea, its mean depth being no more than 45 metres. Its basin shoals near the coasts of France and England, and also toward the Pas-de-Calais, while deepening toward the Atlantic.

"We would direct attention to the submarine terraces which border the coasts as among the principal features of the orography of la Manche. Outside these terraces somewhat numerous banks occur, especially toward the Pas-deCalais, as, for instance, the Bassure, the Vergoyer, and the Colbart, which lie near and parallel with the French coast.

"Note should be made of the central deep which stretches from off the county of Sussex to Finistère. Near cap de la Hague, at the western extreme of Cotentin, it twists and presents irregular ramifications.

"In breadth but slight, in depth it much exceeds the rest of la Manche, reaching even, at the west of cap de la Hayue, to over 160 metres. This central deep corresponds to a submarine valley, and that it has not been scoured out by the currents of $l a$ Manche its characteristics clearly show. It is formed, on the contrary, by a deep cleavage, having a general direction of E.N.E., and, although very narrow, not yet filled by recent deposits.

"Since la Manche is swept by strong currents, it should follow that deposits are not universally received on its bed, which, on the contrary, should frequently be formed of rocks (roches pierreuses) of earlier than the present period; and this, in fact, the soundings show, while these rocks occupy an even greater proportional area of the bed than in other seas.

"In the first place, they cover large areas in the western part of la Manche; they border Brittany and Cotentin, which they join to Jersey and the other Channel Islands; and further they unite Brittany to Cornwall, and Cotentin to the south of England. Cutting out on very irregular boundaries, not only do they spread along the coasts, but pass completely across la Manche, extending even to the deepest parts of its basin and the mid-course of its valley.

"These rocks are certainly very varied; between Brittany, Cotentin, and Cornwall and Devonshire, they are, however, either granites, or belong to the

${ }_{1}$ Lithologie des Mers de France, etc., p.p. 308-9. 


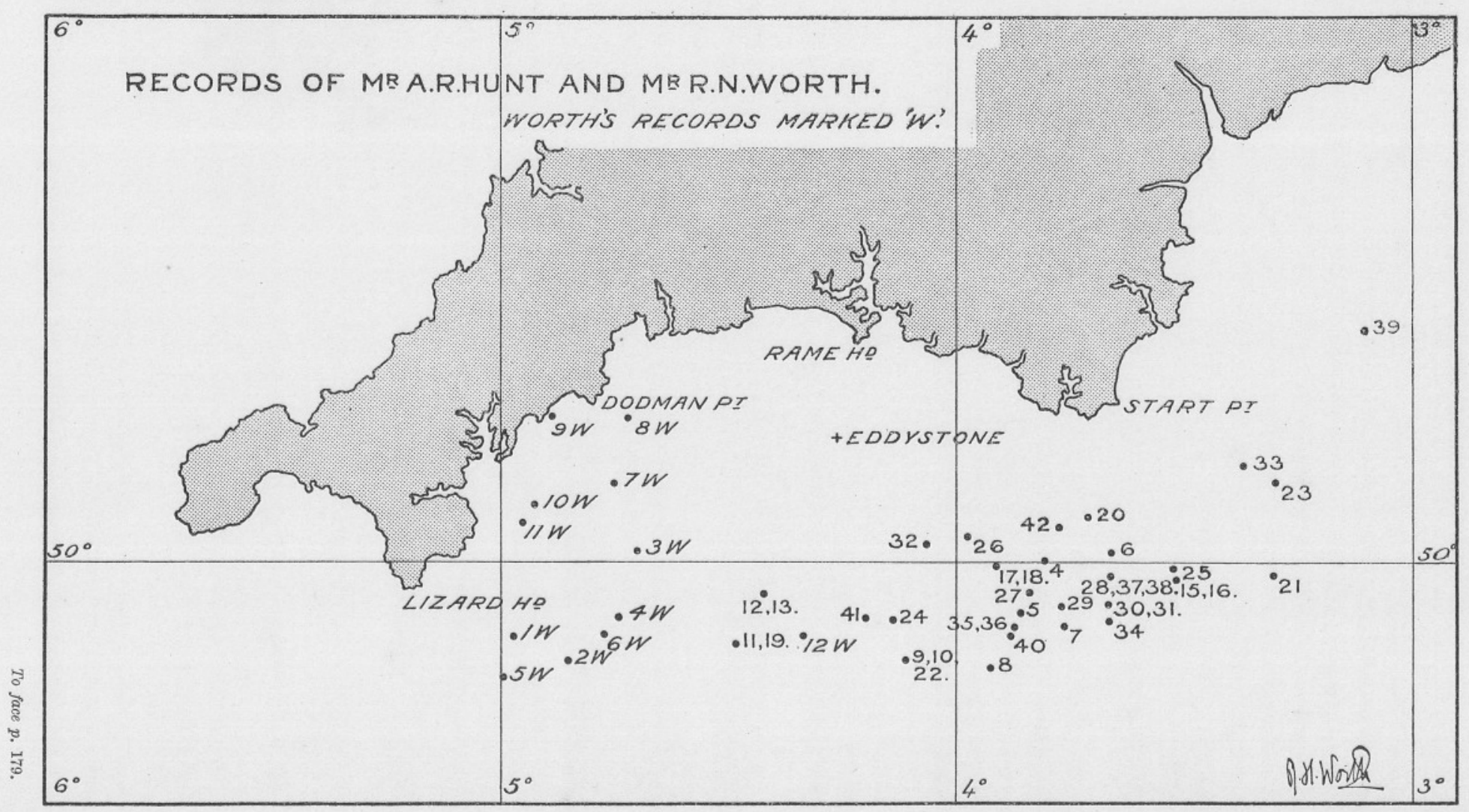


transition formations. Soundings show that they consist in part of detached stones (pierres désagrégées); in addition to which rotten rocks (roches pourries) are frequent around latitude $49^{\circ} 15^{\prime}$, longtitude $7^{\circ} 10^{\prime}$ (W. of Paris), in the mld-course of the valley of la Manche.

"Further to the east the rocks should be submarine extensions of the secondary formations which build up the opposite coasts of France and England. Thus the coast rocks of Calvados, which are limestones of the lower Jurassic period, are continued far out under the sea. And, similarly, white chalk is found at a considerable distance from the chalk cliffs of Fécamp, of Dieppe, and of Saint-Valery en Caux, and is especially prominent on the bed of the Pas-de-Calais," etc.

\section{APPENDIX II.}

Br the kind permission of Mr. A. R. Hunt, M.A., F.G.S., the following petrological notes, abstracted from his papers on the Submarine Geology of the English Channel ${ }^{1}$ are here reproduced.

In his work, Mr. Hunt had the assistance of the late Mr. E. B. Tawney, M.A., F.G.s. (E. B. T.), Prof. T. G. Bonney, M.A., F.G.s. (T. G. B.), and Mr. A. Harker, M.A., F.G.s., (A. H.), and all the notes herein included are taken from the descriptions written by some one or other of these petrologists.

The initials of the authorities, as given above, follow each entry.

Although for present purposes the notes have been somewhat shortened, no variation has been made amounting in any way to more than the exclusion of minor detail.

All bearings are magnetic, and bearings and distances alike are given on the authority of the fishermen who trawled the blocks. Hence minute accuracy can not be expected, but, on the other hand, subsequent experience indicates that probably no very considerable error has been made. (Plate XVII.)

\section{CRYSTALLINE ROCKS.}

Eight Granite. Nos. 2, 19, 20, 27, 34, 35, 39, 42.

H. 2. Doorstep of Brixham Orphanage. A granite of moderately coarse grain and pinkish colour, with large pale flesh-coloured orthoclase twins.

Biotite and muscovite in about equal proportions. Orthoclase largely predominant, but some plagioclase present.

The quartz contains cavities, some with moving bubbles; also microlite needles, and hair-like delicate crystals of undetermined character. Some apatite is present.-E. B. T.

1 Transactions of the Devonshire Associations, 1879, 1880, 1881, 1883, 1885, 1889. 
H. 19. Broken off by trawl about 20 miles S.W. of Eddystone.

Granite of coarse grain. Both white and black micas present. A little triclinic felspar in addition to the orthoclase. The quartz contains large fluid inclusions with bubbles. Apatite is abundant in rather large crystals.-E. B. T.

H. 20. About 10 miles S.W. by S. of Start Point, weight about 15 to 16 cwt.

A coarse grey granite with silvery mica in addition to dark mica. Felspar chiefly orthoclase, but a little triclinic felspar, including microcline, is present. The quartz contains fluid cavities. An occasional tendency to micropegmatic structure.-E. B. T.

H. 27. Trawled 18 miles S.W. of the Start.

A rather fine-grained granite, reminding Prof. Bonney somewhat of granites from one or two localities in the Channel Isles.

- It consists of quartz, felspar (orthoclase, oligoclase (?), and perhaps microcline), and two micas, black and white, the former occasionally somewhat altered.-T. G. B.

H. 34. Trawled 18 to 20 miles S.S.W. of Start Point. Weight 9 or 10 cwt.

A true granite, a good deal decomposed.-T. G. B.

H. 35. Trawled 21 miles S.W. of Start Point. Weight about 5 cwt.

A granite containing quartz, with the usual felspars, hornblende, and brown mica.-T. G. B.

H. 39. Trawled 15 miles S.E. by E. of Berry Head. Weight 4 to 5 cwt. A rather fine-grained granite of a warm greyish colour. It consists of quartz, - containing fluid cavities, with bubbles and some acicular microliths (? rutile) -felspar, somewhat decomposed, both orthoclase and plagioclase (? oligoclase), brown mica, occasionally somewhat decomposed, a little white mica, and iron oxide.-T. G. B.

H. 42. Trawled 12 miles S.W. of Start Point. Weight 3 cwt.

A moderately finely crystalline rock, speckled lighter and darker grey, looking like a granite, with possibly a slight foliation. Consists of quartz, felspar (ortheclase and plagioclase), and a considerable quantity of brown mica, with a rich colour and strong dichroism. Now and then there is a little white mica.-T. G. B.

Four Hornblendic Granite. Nos. 4, 21, 24, 25.

H. 4. Trawled 15 miles S.W. of Start Point. A rounded block measuring $3^{\prime} 6^{\prime \prime} \times 2^{\prime} 3^{\prime \prime} \times 1^{\prime} 8^{\prime \prime}$.

A coarse-grained rock, exhibiting colourless felspar and quartz, black hornblende, and brown mica. Hornblende and biotite abundantly present. Of the felspars, orthoclase and plagioclase seem in almost equal proportions; both are much decomposed and kaolinised in patches. The quartz contains a quantity of hair-like crystals of undetermined nature; besides these are a 
few prismatic microlites, and enclosure of minute cavities. Apatite is well developed also.-E. B. T.

H. 24. Trawled 14 or 20 miles S.S.E. of Start Point. Weight about 4 cwt.

A rather coarse-grained hornblendic granite, of darkish tint; the felspars of slightly pinkish hue. Both hornblende and dark mica are present in abundance. The felspar is much decomposed, and is chiefly orthoclase. Apatite present-E. B. T.

H. 21. Trawled 16 or 17 miles S. of Eddystone. Weight about 5 cwt.

A granite of medium grain, with faint pink-tinted felspars, and in which hornblende is abundantly visible; of biotite there is much less. Though the felspars are much decomposed, plagioclase can be detected in some quantity. Apatite seems nearly absent. Quartzes are clear, but moving bubbles are frequent in the liquid inclusions.-E. B. T.

H. 28. Trawled 15 miles S. of Start Point. Weight 3 to 4 cwt.

To the eye much like No. 24, but differs a little in shade. Biotite more abundant than hornblende; apatite very abundant.-E. B. T.

One Gneiss. No. 36 .

H. 36. Trawled about 21 miles S.W. of Start Point. Weight 8 or 9 cwt. Quartz, felspar (plagioclase predominating), brown mica and some white mica, apatite. Prof. Benney adds: "The rock, I think, is undoubtedly a gneiss, and it is of an Archæan type."-T. G. B.

Three Granitord Gneiss. Nos. 3, 28, 61.

H. 3. Salcombe Block, buried at Brixham Orphanage.

A rather fine-grained granite-looking rock, in which a certain streaky arrangement of the mica is apparent, the felspars fresh and translucent.

The thin slice shows the micas distinctly set in one direction mainly; they wrap around the felspars or larger quartzes. The felspars show little or no kaolinisation; orthoclase more abundant than plagioclase. Both biotite and muscovite are present. The quartz contains numerous delicate, long capillary crystals, and cavities with bubbles. Apatite is present.-E. B. T.

No. 28. Trawled 15 miles S.S.W. of Start Point. Weight 12 cwt.

A very coarse gneiss rather than a granite. The quartz occurs both in larger grains, rather full of cavities, and in aggregates of small granules. The felspar is in parts more decomposed, and replaced by aggregates of secondary products (micaceous and other microliths), or by a dull greenish granular mineral, perhaps an impure epidote, but in parts is fairly well preserved, microcline being common. There are also flakes of an olive-brown older mica, and a few granules of iron peroxide. "This rock has the aspect of a very ancient Archæan gneiss."-T. G. B.

H. 61. Erratic on shore, S.E. of East Prawle.

A light grey rock with the appearance of a fine-grained granite or granitic gneiss. The foliation seen in the slice is not evident in the hand-specimen. 
The rock consists mainly of felspar and quartz, with subordinate biotite, ete. The felspar is chiefly, if not wholly, of triclinic varieties. Much of it is microcline ; there is also some oligoclase with carlsbad, and albite-twinning. Most is clear, but there are cloudy patches in places, which seem due to the development of white mica in minute scales. Quartz occurs in large and small grains, usually composite; strain-shadows are common. The biotite has a marked parallel orientation throughout the slice. It is a deep brown, intensely pleochroic mica, becoming green only by alteration. The other elements of the rock are rare magnetite and green hornblende, with some epidote and other secondary minerals.-A. H.

Two Hornblendic Gneiss. Nos. 33, 44.

H. 33. Trawled about 12 miles S.E. of Start Point.

Quartz abundant in irregular aggregated granules, felspar in occasional grains, with very irregular outline; orthoclase (probably) and plagioclase. Green hornblende, a strongly dichroic variety, in streak-like aggregates of long, slightly fibrous prisms, magnetite, a few films of brown mica, a little apatite, possibly zircon.-T. G. B.

H. 44. Trawled block, lying on Brixham Quay.

A medium-grained felspar-hornblende rock with well-marked banding, the white felspathic and black hornblendic bands being commonly from onetwentieth to one-eighth inch in width. There is no evident fissile structure, and the rock is perhaps to be styled a hornblende-gneiss rather than a hornblende-schist.

Felspar, the dominant mineral, is exclusively plagioclase, apparently a basic labradorite. Inconstant twinning is often seen to be clearly connected with a slight bending of the crystal, and must in great part be secondary and the consequence of strain. Most of the felspar is perfectly clear, but there are also cloudy opaque patches, white by reflected light. The abundant green pleochroic hornblende is in ragged or irregularly bounded crystals. Associated with it is a clear colourless augite. This is often embedded in the hornblende, but there is no clear indication of the latter mineral having originated at the expense of augite. No iron-ore appears in the slice.-A. H.

Three Hornblendic Granitoid Gneiss. Nos. 31, 32, 41.

H. 31. Trawled 18 miles S.S.W. of Start Point. Weight about 3 cwt.

Quartz, felspar, brown mica, a little hornblende, and a little green chloritic mineral, perhaps an alteration product after some of the mica, some apatite. The quartz has rather numerous minute cavities, some empty, some with small moving bubbles. The felspar (which is a little decomposed) is partly orthoclase, but there is a good deal of albite or oligoclase.-T. G. B.

H. 32. Trawled 12 miles S.S.E. of Eddystone. Weight about 7 cwt.

Minerals as in 31 , but in rather different proportions. For instance, there is more hornblende. The state of preservation is not so good.--T. G. B. 
H. 41. Trawled 16 miles S. by W. of Eddystone. Weight 5 to 6 cwt.

A pale-coloured coarse rock with a rather porphyritic structure, the felspar crystals occasionally about an inch long. Quartz containing rather numerous enclosures, chiefly little cavities with small bubbles; felspar, rather decomposed, one crystal in the section is a plagioclase, but the larger crystals resemble orthoclase; white mica; the section shows a good-sized grain of brownish hornblende; some dark granules or grains, probably hematite.T. G. B.

One Microgranulite. No. 40.

H. 40. Trawled 22 miles S.W. of Start Point. Weight 2 or 3 cwt.

The ground-mass a very intimate mixture of quartz and felspar, exhibiting numerous varieties of micrographic structure. Rather rounded crystals of felspar, up to about quarter of an inch in diameter, generally in fair preservation, and in most cases orthoclase. Smaller and less distinct grains of quartz. Irregular patches of a dark mineral, seen in the section to be a green chloritic mineral, often rendered nearly opaque by the association of brown iron oxide.-T. G. B.

One Quartz Felsite. No. 43.

H. 43. Exact locality unknown. Weight about 12 cwt.

The microscope shows grains of quartz and felspar, and clusters of rather small flakes of biotite, scattered in a microgranular matrix of quartz and felspar, with occasional flakes of biotite or a greenish mineral, possibly a chlorite or a variety of hornblende, with sometimes a certain amount of ferrite staining. The felspar varies much in its state of preservation, some grains being very decomposed, others rather clear. Plagioclase is present.-T. G. B.

Two Syenite. Nos. $7,9$.

H. 7. Trawled about 20 miles S.W. by W. of Start Point. Weight about 4 ewt.

A dark green rock of coarse grain, felspars opaque, tinted with pale green and mixed with black hornblende in about equal proportions. Microscopic examination shows the felspars so much decomposed that they are not individually determinable; many are certainly plagioclase from indications of multiple twinning, whether plagioclase or orthoclase is predominant cannot be determined. There is a considerable amount of quartz present, of which much is certainly secondary ; it is seen replacing felspar crystals and originating from their decomposition. The hornblende is green in colour; by decomposition it gives rise to chloritic matter, with which some epidote is mixed; epidote may also be seen in the decomposed felspars. Apatite crystals are large, and specially abundant near the hornblende. Ilmenite is also present.-E. B. T.

H. 9. Dredged 20 miles S. of Eddystone. Weight from $\frac{1}{4}$ to $\frac{1}{2}$ cwt.

The same minerals occur as in No. 7, but it differs by the abundance of quartz, the substitution mostly of chlorite for hornblende, and the obscure linear arrangement of the same.-E. B. T.

NEW SERIES. - VOL. VIII. NO. 2. 
Four Diorite. Nos. 1, 16, 22, 62 .

H. 1. From Salcombe fishing grounds. Weight $9 \frac{1}{4} \mathrm{cwt}$.

Macroscopically this rock shows a pale yellowish-white felspar and a very dark green hornblende, which appear to be rather closely set in a dull yellowgrey rather compact matrix. The slide shows felspar crystals, which have a tolerably regular outline, but are, as a rule, much decomposed, the mineral being often converted into an aggregate of earthly granules. In some of the crystals the polysynthetic twinning of plagioclase is still visible. The hornblende is a rich green colour, with fairly strong dichroism, and tolerably perfect crystal outlines. There are several grains of quartz, and a few clusters of small flakes of brownish mica, and a little magnetite.-T. G. B.

H. 16. Trawled 17 miles S. of Start Point. Measures $2^{\prime} 6^{\prime \prime} \times 1^{\prime} 10^{\prime \prime} \times 1^{\prime} 2^{\prime \prime}$.

A sap-green coloured rock, in which the large actinolite crystals chiefly catch the eye; it is coarsely crystalline. The microscope shows the long actinolite crystals, green in colour, and at the borders often connected with diverging bundles and needles of pale green crystals, also actinolite, which penetrate the felspars.

The plagioclase still preserves its twinning for the most part, but much of it is attacked by decomposition, and it is everywhere permeated by long actinolitic fibres and particles. Apatite is present. Secondary quartz has been deposited in little veins and interstices.-E. B. T.

H. 22. Trawled 20 miles S. of Eddystone. Weight about 5 cwt.

Quartz is not so abundant as in granite, while the microscopic examination shows that the prevailing felspar is triclinic. Hornblende is abundant, and also dark mica; the latter occurs not so much as scattered crystals as in groups of diverging or matted prisms. Apatite is abundant; magnetite grains occur also mixed with the mica.-E. B. T.

H. 62. Erratic on shore near Gorah Run, E.S.E. of Prawle.

A moderately coarse granitic rock, in which black hornblende is conspicuous, set in white felspar and grey quartz. Lustrous flakes of dark mica are also seen.

Green hornblende and brown biotite are both well represented. The former often shows faces of the prism-zone, but never builds very perfect crystals. One section, three-eighths inch in diameter, is studded with little grains and rounded crystals of felspar, and some of quartz. The smaller crystals of hornblende are sometimes twinned on the usual law. Much of the biotite, which tends to build stout flakes, is bleached and partially decomposed. The felspar tends to form rectangular crystals, and is chiefly, if not wholly, oligoclase with rather close albite-lamellation. The crystals are often cloudy from alteration, especially in the interior. The clear quartz often shows strain-shadows. The only other original mineral is a little apatite.

Quartz is more abundant than in most ordinary quartz-diorites.-A. H. 
Two Diabase. Nos. 17,37 .

H. 17. Trawled 17 to 18 miles S.W. by W. of Start Point. Weight 7 to 8 cwt.

A dark green rock of medium grain, with minute specks of pyrites. A diabase of ordinary type. The plagioclase is much decomposed, the twinning being often lost. Quartz has been secondarily deposited. The augite has also been partly attacked by decomposition, and chloritic matter has resulted thereby. A little apatite is present. Magnetite or black oxide is much more abundant than the pyrites.-E. B. T.

H. 37. Trawled 15 miles S.S.W. of Start Point. Weight 7 to 8 cwt.

A rather compact, dull, greenish-grey crystalline rock. Microscopic examination shows it has once been a fine-grained but holocrystalline rock, composed mainly of plagioclase felspar, augite, and some iron peroxide; but it is now composed of more or less altered felspars, associated with viridite and chloritic minerals, epidote and other secondary products, and perhaps some altered augite.-T. G. B.

Three Gabbro. Nos. 8, 15, 38.

H. 8. Trawled about 25 miles S.W. of Start Point. Weight 5 to 6 cwt.

A coarse-grained rock consisting of white opaque felspar crystals and yellowish-grey diallage. Microscopic examination shows no other constituents ; the felspar is almost entirely decomposed, scarcely showing original optical features. The diallage at borders sometimes undergoes a change into actinolite.-E. B. T.

H. 15. Trawled about 16 miles S. of Start Point. Measures $2^{\prime} 8^{\prime \prime} \times 1^{\prime} 8^{\prime \prime}$ $\times 1^{\prime} 6^{\prime \prime}$.

To this block some 'killas' was adherent, so that it was a junction specimen. The diallage scarcely retains its own physical properties; much of it has become altered to an aggregate of diverging fibrous, colourless or pale greenish crystals, which may probably belong to the actinolite group. The plagioclase is in places opaque from decomposition, and is everywhere much penetrated by the pale green actinolite microlites.-E. B. T.

H. 38. Trawled 15 miles S.S.W. of Start. Weight $10 \mathrm{cwt}$.

A moderately coarse-grained compound of a bluish-white felspar and a dull green mineral. Microscopic examination shows that it is a considerably altered gabbro. The plagioclastic felspar is to a very large extent replaced by micromineral products, such as occur in the so-called saussurite. The augite or diallage is replaced by hornblende, sometimes normal in aspect, sometimes rather actinolitic. An iron oxide and a little apatite are present, but no indication of former olivine.-T. G. B.

One Serpentine. No. 6.

H. 6. Trawled 13 miles S.S.W. of Start Point. Weight 5 cwt.

Mottled red and green colour, with steatite veins, and precisely like some of the Cornish varieties. 
The microscope shows that none of the olivine is left unchanged in the meshes; in the serpentine are abundance of scattered hæmatite blotches. Veins of chrysolite, or steatite, have a central line of black iron oxide bordered often with red. Some of the enstatite is left unchanged, but only in fragments in the middle of bundles of talcose crystals and steatite, to which it seems to give rise by decomposition.-E. B. T.

One Trachyte. No. 29.

H. 29. Trawled 18 miles S.W. by S. of Start Point. Weight 3 or 4 cwt. Under the microscope this rock exhibits a glassy base, in part but probably not wholly devitrified, with a fairly well-marked fluidal structure. It has undergone a certain amount of secondary change in the development of various microlithic minerals, showing bright colours between crossed nicols, and of specks of viridite. In this ground-mass occur numerous crystals of felspar, sometimes rather rounded or broken-looking, which contain microliths or glass inclusions, more or less altered. Some are plagioclase, probably oligoclase, others appear to be orthoclase. There is a filmy green mineral associated with streaks of opacite, which very probably replaces a mica, and there are some grains of iron peroxide. No quartz grains are to be seen in the slide; there may be some apatite.-T. G. B.

\section{NON-CRYSTALLINE ROCKS.}

Two Conglomeratic-grit. Nos. 5, 26.

H 5. Trawled 20 miles S.W. of Start Point. Weight 10 cwt.

A coarse grit containing a few pebbles of rolled vein quartz, flesh-coloured felspar, and fragments of fine-grained felsite-like rock. The rock has much the appearance of an arkose.-E. B. T.

H. 26. Trawled 15 or 20 miles W.S.W. of Eddystone. Weight 3 or 4 cwt.

A moderately coarse grit composed wholly or almost wholly of rounded grains of whitish quartz, cemented by pyrite.-T. G. B.

One Killas. Attached to No. 15.

H. 15. Trawled 16 miles S. of Start Point.

One Triassic Sandstone. No. 10.

H. 10. Trawled 20 miles S. of Eddystone.

An unrolled fragment of a reddish-brown sandstone, similar in appearance to the Triassic sandstones abundant either in mass or as outliers on the coast of South Devon.

One Neocomian Sandstone. No. 23.

H. 23. Trawled 15 miles S.E. of Start Point. Weight 9 to $10 \mathrm{cwt}$.

A sandstone with green grains; it has all the appearance of Neocomian sandstone, as in Kent.-E. B. T. 
Four (Sets) Chalk Fuints. Nos. 11, 12, 14, 18.

H. 11. Trawled 20 miles S.W. of Eddystone.

Some twenty chalk flints; one weighs $6 \mathrm{lb}$, and is perfectly unrolled.

H. 12. Trawled 15 miles S.W. of Eddystone.

A small flint about $8 \mathrm{oz}$. in weight.

H. 14. Trawled 20 miles S.W. of Start Point. Weighs $3 \mathrm{lb} .2 \mathrm{oz}$. and 2 lb. 14 oz. respectively.

H. 18. Trawled 17 or 18 miles S.W. by W. of Start Point. One flint weighed $1 \mathrm{lb} .9 \frac{1}{2} \mathrm{oz}$.

One Limestone. No. 13.

H. 13. Trawled 15 miles S.W. of Eddystone.

A small piece of buff-coloured limestone, riddled through and through by molluses and other marine borers.

One Grit. No. 30.

H. 30. Trawled 15 to 20 miles S.S.W. of Start Point.

This is a small stone, measuring about $8^{\prime \prime} \times 6^{\prime \prime} \times 4^{\prime \prime}$, of fine grit, and may well have been used for ballast. Its evidence is accordingly valueless.

\section{APPENDIX III.}

The observations of the late Mr. R. N. Worth, ${ }^{1}$ F.G.S.

The bulk of the material was obtained for Mr. Worth by the late Mr. Matthias Dunn, of Mevagissey; it was all brought up entangled in the hooks of bolters or long-lines. All bearings are magnetic. (Plate XVII.)

"The evidence that the rocks were in situ when entangled (partly by the marine growths upon them, and partly by their irregularities and the holes bored by Pholades) is clear. With two exceptions only, the specimens retained the characteristics of the original bedding."

W. 1. S.E. Lizard, 10 miles.

Fine-grained, soft, red Triassic sandstone, in layers $1 \frac{1}{2}$ to 2 inches thick.

W. 2. S.E. Lizard, 15 miles.

Triassic sandstone of coarser grain, mottled red and grey.

W. 3. S.E. Manacles Rocks, 16 miles.

Fine-grained soft sandstone, grey with a passing tinge of red in places, in parts highly micaceous, containing both black and white micas.

W. 4. S.S.E. Falmouth Castle, 18 miles.

Fine-grained, compact, red, jaspideous sandstone, much bored. The specimen shows portions of two joint faces, at right angles to each other.

w. 5. S.W. by S. Deadman, 25 miles.

a. Chocolate marl, spotted white. The edges of this nodule were rounded, but it could hardly be called rolled.

${ }^{1}$ Quarterly Journal of the Geological Society, Vol. XLII, 1886, pp. 313-15. 
b. A "Potato Stone," partially coated with marl and filled with pinkish calcite. The inside of the shell was studded with small brilliant pyramids of quartz.

c. Grey sandstone.

d. A nodule of Triassic Trap. A hard red rock, slightly micaceous; very closely resembles some varieties of the Triassic Trap of Thorverton, with affinities to those of Pocombe and Cawsand.

W. 6 . S. by W. Deadman, 20 miles.

a. A light salmon-tinted drab calcareous sandstone, in a slab nearly two feet in longest diameter, the under surface intact and slightly pitted.

$b$. Granitic and granitoid pebbles.

c. Quartzite pebbles.

d. Flints.

W. 7. S. Deadman, 7 miles. $^{1}$

Slabs of Triassic conglomerate, evidently torn from a submarine reef-point, sides, and upper and lower surfaces being intact in each instance, and the only broken surface that of fracture from the parent rock. Examined microscopically this conglomerate proves to contain pebbles of slate, grits, vein quartz, quartz-felsite, and andesite.

W. 8. S.E. Deadman, 3 miles.

W. 9. W. Deadman 4 miles.

W. 10. S.W. Deadman, 10 and 12 miles.

W. 11. S. by E. Deadman, 27 miles.

No Trias found at any of the last four positions.

W. 12. S.W. Falmouth, 10 miles.

Ochreous volcanic ash.

1 “Additional Notes on the Cornish Trias," Trans. Royal Cornwall Geological Society, 1891.

\section{EXPLANATION OF PLATES.}

Plate VI. (Opp. p. 123). (1). Micro-pegmatite, with characteristic intergrowth of felspar and quartz. (2). Central portion of (1), more highly magnified.

", VII. (Opp. p. 135). (1). Hornblende-gneiss. Showing 3 garnets ; immediately beneath the central one a small, uniformly tinted area of chlorite. (2). Chlorite schist with crushed plagioclase felspar.

, VIII. (Opp. p. 143). Grit, with derived fragment of older rock (A-B).

" IX. (Opp. p. 151). (1). Hard yellow chalk, with derived inclusion of earlier chalk rock. (2). Section of same, showing foraminifera, shell fragments and other organic remains.

„ X. (Opp. p. 153). Decomposed black flint, with shell fragments and complete foraminifera in carbonate of lime. (2). Lower part with carbonate of lime removed.

XI. (Opp. p. 156). Eocene limestone.

XII. (Opp. p. 157). Eocene limestone, showing foraminifera.

, XIII. (Opp. p. 163). Chart, Start to Hand Deeps. Illustrating Dr. Allen's StartEddystone dredgings.

XIV. (Opp. p. 166). Chart showing distribution of granite and gneiss.

XV. (Opp. p. 168). , , " , , trias, rhaetic, and lias.

XVI. (Opp. p. 169). ", , , , hard yellow chalk.

XVII. (Opp. p. 179). ,, ,, location of dredgings recorded by Mr. A. R. Hunt and Mr. R. N. Worth. 